\title{
EGYSZÜLŐS CSALÁDOK ÉS POLITIKÁK MAGYARORSZÁGON ÉS EURÓPÁBAN
}

\section{Monostori Judit}

\section{ÖSSZEFOGLALÓ}

Az egyszülős családok szegénységi kockázata minden országban lényegesen meghaladja a társadalmi átlagot és a gyermeket nevelő, párkapcsolaton alapuló családok kockázati mutatóját is. Mit tehet ilyenkor az állam? Milyen mértékben tud segíteni ezeknek a családoknak? Milyen mértékben akarja segiteni őket? Tanulmányunkban ezekkel a kérdésekkel foglalkozunk. Rámutatunk arra, hogy az egyszülős családok Európa egyetlen országában sem preferált csoportjai a társadalompolitika különböző területeinek. Ennek részben ideológiai okai vannak, azaz az európai politikák próbálják elkerülni annak a látszatát, hogy támogatják, ha csak egy szülő neveli a gyermekeket. Másrészt erős a visszaélésektől való félelem is, azaz, hogy a gyermeket nevelők 'csak papíron élnek külön', hogy állami transzferekre tegyenek szert.

Magyarországon az elmúlt években lényegesen növekedett a párkapcsolaton alapuló és az egyszülős gyermekes családok szegénységi mutatói közötti távolság. Ennek az az oka, hogy míg az előbbi csoport esetében az állami újraelosztás jelentősen tudta csökkenteni a szegénységnek kitett csoportok arányát, addig az egyszülős családok szegénységi kockázata nem változott. Írásunkban áttekintjük, hogy hogyan járulnak hozzá ehhez a férfiak és a nők munkaerőpiaci helyzetének különbségei, az apaság intézményének alakulása, a gyermekellátórendszer müködése és az állami redisztribúció.

Tárgyszavak: egyszülős családok, családpolitika, társadalompolitika, szegénység

Monostori Judit, KSH Népességtudományi Kutatóintézet

E-mail:monostori@demografia.hu 


\section{BEVEZETŐ}

Társadalmi egyenlőtlenségek minden társadalomban léteznek, amelyeket részben a piac, részben pedig az állam újraelosztási mechanizmusai gerjesztenek. Annak ellenére van ez így, hogy ez utóbbiról, azaz az állam újraelosztási tevékenységéről gyakran hangoztatjuk, hogy célja a piac által generált egyenlőtlenségek csökkentése. Valójában számos empirikus bizonyiték áll rendelkezésre azzal kapcsolatban, hogy az állami újraelosztás is új egyenlőtlenségeket hozhat létre vagy már meglevő egyenlőtlenségeket erősíthet fel. Erre talán az egyik legszemléletesebb példa, hogy miközben az utóbbi évtizedben a párkapcsolaton alapuló, legalább három gyermeket nevelő családok szegénységi mutatói lényegesen javultak, addig a gyermeküket egyedül nevelő szülők mutatói érdemben nem változtak (Központi Statisztikai Hivatal, 2019a). Ezáltal a gyermekes családok szegénység szempontjából két legveszélyeztettebb csoportja közötti távolság az utóbbi évtizedben lényegesen megnövekedett. Ez alapvetően annak köszönhető, hogy a családtámogatási rendszer különböző elemeit az egyes családtípusok eltérő mértékben tudják igénybe venni. A párkapcsolaton alapuló családok, különösen a három vagy több gyermeket nevelők a mai családpolitika preferált csoportjának tekinthetők, míg az egyszülős családokról ez nem mondható el.

A tanulmány áttekinti azokat a nehézségeket amelyekkel az egyszülős családoknak meg kell küzdeniük, megvizsgálja, hogy reflektál erre a magyar társadalompolitika; milyen jó gyakorlatokat találunk Európa különböző országaiban; melyek azok a területek, ahol a társadalompolitika hatékonyabb beavatkozására lenne szükség, hogy a gyermeküket egyedül nevelő szülők családjainak életkörülményei érdemben javuljanak.

Az európai és a hazai szakpolitikák kritikai értékelésére ez a tanulmány nem vállalkozik, melynek több oka is van. Egyrészt számos szakterületen hiányoznak azok az adatok, amelyek a családi hátteret (pl. van-e gyermeke, akivel egy háztartásban él, egyedül vagy párkapcsolatban neveli) is figyelembe véve vizsgálják a nők és a férfiak, illetve a nők különböző csoportjai közötti egyenlőtlenségeket. Másrészt eléggé felületesek, nehezen értelmezhetők azok a szakpolitikai leírások (pl. a Mutual Information System on Social Protection [MISSOC] adatbázisa), amelyek próbálják a munkaerőpiaci politikák, a családpolitika, a segélyezés stb. szempontjából számbavenni Európa országainak gyakorlatát. Figyelembe kell venni azt is, hogy az egyes intézkedések gyakorlati megvalósulásáról nagyon kevés információnk van. Tipikus példa a munkaerőpiaci szereplők (munkavállalók és munkadók) közötti viszony szabályozása, amely- 
ben a törvény betűje és a mindennapi gyakorlat eltérhet egymástól. Ilyen lehet a bölcsődei vagy az óvodai nyitvatartás szabályozása is. Nevezetesen hiába írják elő a hosszabb nyitvatartást, ha például késő délután már nincs megfelelő számú szakember az intézményben, ha összevonják a csoportokat, vagy ha nap mint nap szúrós szemmel néznek azokra a szülőkre, akik későn viszik el a gyerekeiket. A jogi szabályozás és a gyakorlat szétválásának vizsgálata komoly feltétele annak, hogy egy-egy intézkedés tényleges hatását is felmérjük.

Tanulmányunkban az európai példák és jó gyakorlatok is inkább csak illusztratív célokat szolgálnak. Az egyes szakpolitikai intézkedések hatása ugyanis függ az intézményi közegtől, attól a kultúrától, amelyben működésbe lép. Számos olyan példát sorolunk fel, amely bizonyítja, hogy nincsen olyan intézkedés, amely minden közegben hasonló hatékonysággal müködne, sőt gyakran még az intézkedés hatásainak az iránya is eltérő lehet.

Tanulmányunk első fejezetében adunk egy áttekintést arról, hogy mennyire elterjedtek az egyszülős családok Európa különböző országaiban. Ezután megpróbáljuk felvázolni, hogy milyen általános vonások jellemzik az egyszülős családokra irányuló politikákat, illetve bemutatjuk azt az értelmezési keretet, amelyen keresztül ezeket a szakpolitikákat megfigyeljük. Majd néhány főbb területen megvizsgáljuk az egyszülős családokkal kapcsolatos hazai és európai politikákat.

\section{EGYSZÜLŐS CSALÁDOK ELTERJEDTSÉGE}

A legutóbbi, 2016-os mikrocenzus adatai szerint a 18 éves és fiatalabb gyermekeknek 18\%-a egyszülős családban nevelkedik. Minél idősebb korosztályt vizsgálunk, annál magasabb a mutató értéke. Adataink szerint a 17-18 éveseknek már 26\%-a él kizárólag az egyik szülőjével. Ennél azonban lényegesen magasabb azoknak az aránya, akik eddigi életük alatt már megtapasztalták szüleik kapcsolatának felbomlását, az egyik szülő elveszítését, tehát az egyszülős családban élést. Erre utal, hogy a 0-18 évesek 31\%-a nem intakt családban él, azaz ahol az ott élő gyermekek legalább egyike nem mindkét vér szerinti szülőjével nevelkedik.

Az egyszülős családok aránya Európa más országaiban is számottevő, noha európai szinten viszonylag nagy különbségeket találunk a tekintetben, hogy a

'A számításokat a 2016-os mikrocenzus adatai alapján végeztem. Nem intakt családnak az egyszülős családok és a mozaik családok összességét tekintettem. 
gyermeket nevelő családoknak mekkora hányada egyszülős. Azonos módszertannal 2011-ben végrehajtott népszámlálások adatai szerint ezeknek a családoknak az aránya a dél-európai országokban a legalacsonyabb, 10-15\% között mozog. A legmagasabb arányokat viszont elsősorban közép-kelet illetve a kelet-európai országok körében találjuk, így például Magyarországon, Csehországban, Szlovéniában és a Balti országokban. A nyugat-európai térségben, főként az Egyesült Királyságban nagyon magas a gyermeküket egyedül nevelők aránya (1. ábra).

\section{1. ábra: Egyszülős családok aránya a gyermeket nevelő családok körében, 2011}

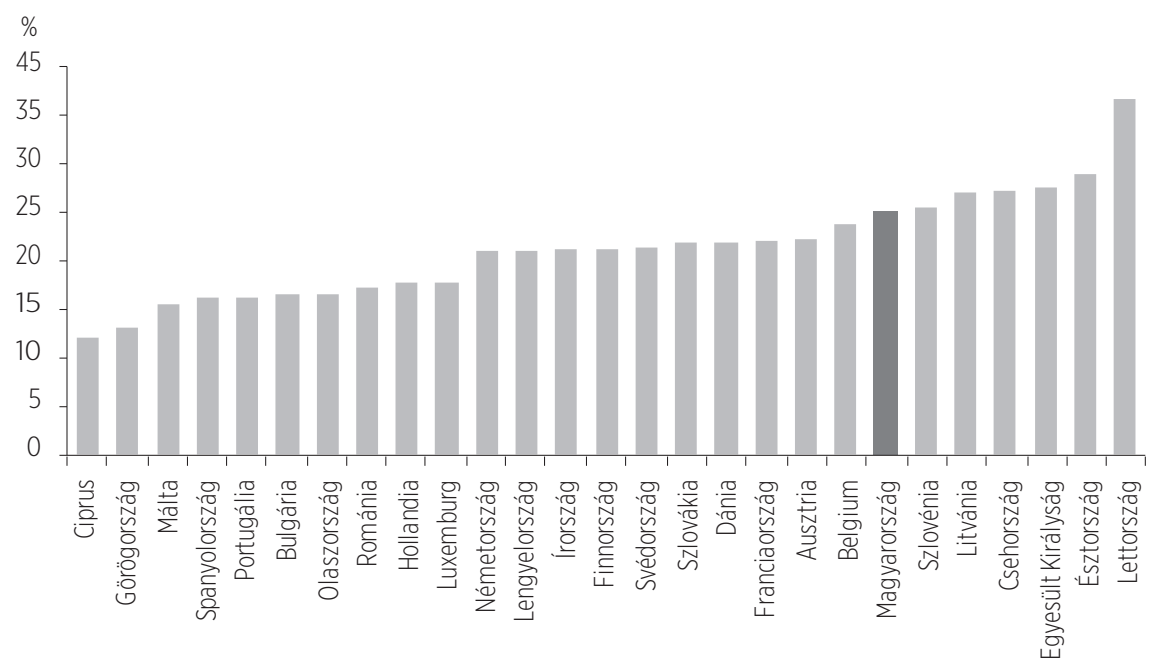

Forrás: Saját számítás Eurostat cenzus adatok alapján (Eurostat, 2015).

Megjegyzés: Az adatok azokra a családokra vonatkoznak, ahol a háztartásban csak egy család él. A gyermekes családok körében azok kerültek számbavételre, ahol 25 évnél fiatalabb gyermeket neveltek a szülő(k).

Az egyszülős családok döntő többségében az anya neveli a gyermekeket. Magyarország azon országok körébe tartozik, ahol ez a „női túlsúly” különösen nagy. 2011-ben mindössze a családok 13\%-a volt olyan, ahol az anya hiányzott a családból, míg a családok 87\%-ában a háztartástól külön élő szülő az apa volt (2. ábra). E vonatkozásban nagyon nehéz valamilyen logikus csoportosítást találni az európai országok körében, mert más-más okok állhatnak amögött, hogy néhány országban miért magasabb az apás családok aránya. Svédországban például azt feltételezhetjük, hogy az apai jogok sokkal magasabb szinten vannak, mint másutt, ezért európai összehasonlításban a gyerekek gyakrabban kerülnek elhelyezésre az apáknál. Romániában vagy Bulgáriában viszont egészen más a helyzet. Ezekben az országokban feltételezhetjük, hogy sok anya dolgozik/él külföldön és ezért magas a mutató értéke (Isd. ezekről: Blaskó, 2016). 


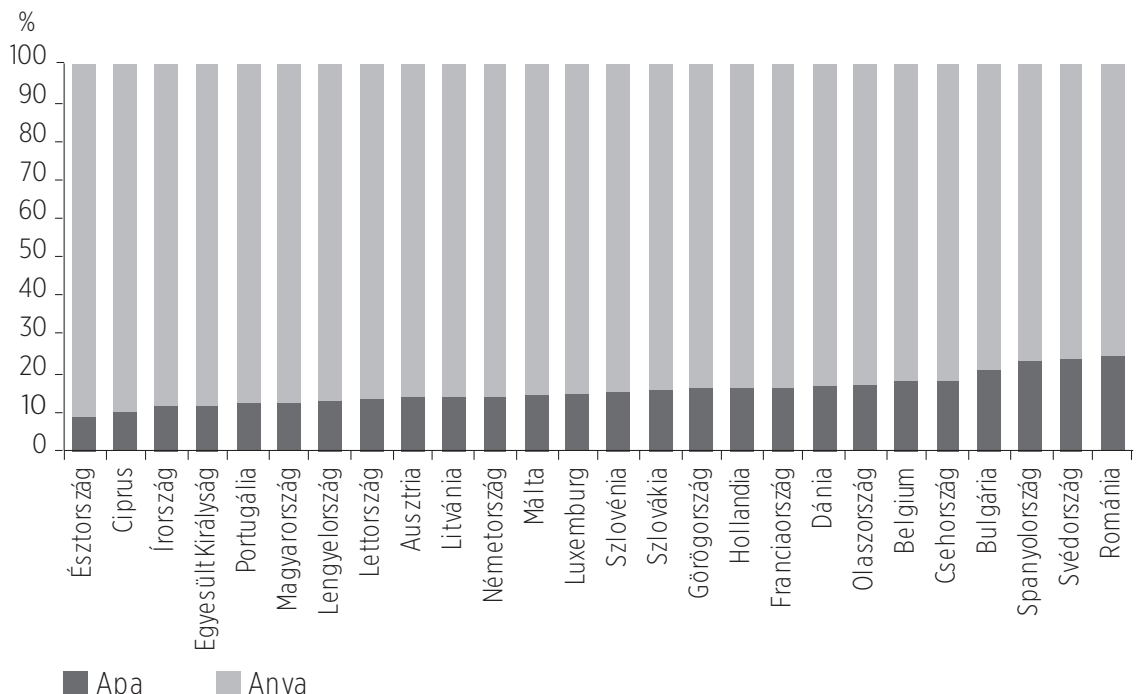

Forrás: Saját számítás Eurostat cenzus adatok alapján (Eurostat, 2015).

Megjegyzés: Az adatok azokra a családokra vonatkoznak, ahol a háztartásban csak egy család él. A gyermekes családok körében azok kerültek számbavételre, ahol 25 évnél fiatalabb gyermeket neveltek a szülő(k).

Itt utalnánk egy nagyon fontos mérési problémára, amely a jövőben a magyar kutatásokban is egyre jelentősebbé fog válni. Ez pedig az osztott elhelyezés kérdése, amikor a gyermek az ideje felét egyik, míg másik felét a másik szülőnél tölti. Jelenleg ezt az élethelyzetet a statisztikák nem kezelik, noha néhány országban (pl. a skandináv országokban) ez igen elterjedt gyakorlat. Magyarországon nincsenek arra vonatkozóan adataink, hogy az osztott felügyelet mennyire elterjedt, hiszen ez a gyakorlat nem feltétlenül kötődik egy jogi aktushoz, így az adminisztratív adatok ebben nem adnak eligazítást.

\section{EGYSZÜLŐS CSALÁDOK AZ EURÓPAI TÁRSADALOM- POLITIKÁKBAN: ÁLTALÁNOS VONÁSOK}

Ha áttekintjük az európai országok egyes szakpolitikáit, kiemelten a családpolitikai, munkaerőpiaci és segélyezési alrendszereket, akkor általánosságban azt állapíthatjuk meg, hogy nincsen olyan európai ország, ahol az egyszülős családok erőteljesen kiemelt célcsoportként jelennek meg, szemben például a három vagy több gyermeket nevelő, párkapcsolaton alapuló családokkal, akikre számos vonatkozásban külön szabályozás van érvényben. Ők jellemzően a családpolitika 
kedvezményezettjei, rájuk több országban is vonatkoznak munkaerőpiaci támogatások, számtalan ellátáshoz, szolgáltatáshoz térítésmentesen jutnak hozzá, és igen jelentős adókedvezményeket vehetnek igénybe. Pedig a párkapcsolaton alapuló, legalább három gyermekes családok a legtöbb európai országban kevesebben vannak, mint a gyermeküket egyedül nevelő szülők (Eurostat, 2015), és az anyagi nehézségek tekintetében sincsenek rosszabb helyzetben (Eurostat, 2018a).

\section{Az egyszülős családok diszpreferálásának lehetséges okai}

A családpolitikai diszpreferálásnak egyik oka lehet, hogy népesedéspolitikai szempontból a három vagy több gyermeket nevelők fontosabbak lehetnek egy adott kormányzat számára, hiszen ezekben a családokban több gyermek nevelkedik, ezek a családok a későbbiekben több potenciális keresőt bocsátanak a munkaerőpiacra, mint például az egyszülős családok, ahol a gyermekszám jellemzően az átlagos alatti.

A másik ok lehet, hogy az egyszülős családok támogatása visszaélésekre adhat alapot. Ha az egyszülős családok bármely társadalompolitika kiemelt célcsoportja, akkor lehetnek olyanok, akik „,csak papíron válnak vagy költöznek szét”, hogy a kedvezményeket megkaphassák. A kormányzat ezeket a visszaéléseket csak nagy adminisztratív költségek mentén tudná visszaszorítani, ami komoly ellenérv az egyszülős családok támogatása mellett.

A harmadik lehetséges érv ideológiai természetü, miszerint az egyszülős családok támogatása azt a képzetet sugallná, hogy az adott kormányzat e családforma mellett áll, ez pedig például a konzervatív kormányzatú országokban nem illeszthető össze egy tradicionális családmodell ideálját hirdető iránnyal. Különösen élesen jelenhet meg ez a kritika azoknak a családoknak a támogatásában, amelyekben az anyák egyedül vállalják a gyermekeiket. Egy ezzel kapcsolatos politikai vita zajlott például az Egyesült Államokban az 1990-es évek legelején, ahol a konzervatív amerikai politikusok úgy érveltek, hogy az addig érvényben lévő segélyezési rendszer alapvetően a szegény, nem házas, de gyermeket nevelő szülőket támogatja. A segély folyósítása hozzájárult ahhoz, hogy folyamatosan csökken a házasságkötések száma, miközben növekedtek a válási mutatók, és emelkedett a házasságon kívül született gyermekek aránya. Ráadásul a rendszer további gyermekvállalásra ösztönzi a nem házas nőket, hiszen egy újabb gyermek érkezésével a segély összege automatikusan megemelkedik. Politikai harcuk eredményeként 22 államban - elsőként New Yersey-ben - egy új 
programot (Transitional Aid for Needy Families [TANF]) vezettek be, aminek az egyik kulcseleme az volt, hogy ha az anya segélyt kap, akkor egy újabb gyermek születésével a segély összege automatikusan nem emelkedik meg.

Nem tudjuk, hogy Európa különböző országaiban ezek az érvek és tapasztalatok mennyire vannak jelen, mennyire legitimálják, hogy az egyszülős családok korántsem tekinthetők a társadalompolitikai intézkedések kedvezményezettjeinek. Az viszont bizonyos, hogy bármelyik érvelés logikáját is vesszük, mindenképpen találhatunk benne könnyen megcáfolható elemeket.

Vegyük azt az érvet, hogy az egyszülős családokban kevesebb gyermek születik, így ezek a családok nem kapcsolhatók az olyan népesedéspolitikai célokhoz, mint például a születések számának növelése. Az valóban igaz, hogy az egyszülős családokban alacsonyabb az átlagos gyermekszám, ugyanakkor látni kell azt is, hogy ennek alapvetően az az oka, hogy az esetek egy részében termékenységi szempontból megtört életpályákról beszélünk. Vagyis nem feltétlenül arról van szó, hogy ezek a szülők kevesebb gyermeket szerettek volna, hanem arról, hogy a párkapcsolat felbomlása megakadályozta őket a vágyaik megvalósításában. Ha viszont újabb párkapcsolatot tudnak kialakítani, akkor ott újabb gyermekek is születhetnek, ami illeszkedhet olyan népesedéspolitikai célokhoz, mint például a születések számának növelése.

A visszaélések lehetőségére utaló érvek sem indokolják, hogy egy ilyen nagyszámú, és társadalmi helyzetét tekintve kedvezőtlen helyzetben levő csoport diszpreferálva legyen, hiszen ezen az alapon megszüntethető lenne a segélyezés, az adókedvezmények rendszere és minden más olyan újraelosztási mechanizmus, ahol visszaélésekre van lehetőség. A visszaélések megjelenéséből nem az következik, hogy nem kell támogatni egy társadalmi csoportot, hanem vissza kell szorítani a visszaélések lehetőségét, hogy szigorúbb ellenőrzési metódusokat kell bevezetni. Továbbá számtalan olyan eszköze lehet a családpolitikának, amelyeknél a visszaélés lehetősége nem merül fel, mint például a tartásdíj fizetésének állami kontrollja. Nyilvánvalóan nem növelné a párkapcsolatok felbomlásának arányát egy olyan állami intézmény vagy eszköz feállítása, amely segítené a gyermeküket egyedül nevelő szülőket abban, hogy a gyermek után járó tartásdíjhoz hozzájussanak.

A harmadik, ideológiai érv ellen olyan fontos alapértékeket lehetne szembe állítani, mint a választás szabadsága, a magánélet védelme, a minden gyermeket megillető alapjogok stb. Másrészt semmi nem garantálja, hogy a kétszülős családok biztosabb hátteret tudnak nyújtani egy gyermek számára, illetve a gyermek érzelmi szükségletei kevésbé lennének kielégítve egy egyszülős családban. Számos európai kutatás jutott arra az eredményre, hogy az egyszülős család- 
ban nevelkedő gyermekek jóllétére, iskolai előmenetelére, érzelmi fejlődésére nem az a tény hatott negatívan, hogy egyszülős családban nőttek fel, hanem, hogy rosszabb anyagi körülmények között nevelkedtek, az anyagi deprivációnak számos formáját élték meg. Ez részben abból következik, hogy egy szelekciós hatás is érvényesül, nevezetesen, hogy az alacsonyabb iskolai végzettségüek, a szegényebbek köréből nagyobb valószínűséggel kerülnek ki az egyszülős családok (Fransson et al., 2018; Harkness and Salgado, 2018; Treanor, 2018). Empirikus kutatások azt sem tudják egyértelmüen kimutatni, hogy a gyermeküket egyedül nevelő szülők támogatása arra ösztönözné az anyákat, hogy ne kössenek házasságot, hogy a nekik járó támogatások miatt több gyermeket vállaljanak házasságon kívül (Isd. a fentebb bemutatott TANF-vita az USA-ban: Bitler et al., 2004; Grogger and Bronars, 2001; Jagannathan and Camasso, 2003). Végül pedig azt is hangsúlyozni kell, hogy az egyszülős családoknak egy meghatározó része özvegyülés útján jön létre, amely egy olyan élethelyzet, amikor az életben maradt szülő már egészen biztosan nem számíthat a másik segítségére. Ezekben az esetekben különösen indokolt a gyermeküket egyedül nevelők társadalmi szintủ támogatása.

\section{Az egyszülős családokat érintő társadalompolitikák lehetsé- ges modelljei}

Mivel az egyszülős családokra vonatkozó társadalompolitikák nem kiemelt területei az európai családpolitikai, munkaerőpiac politikai és segélyezési rendszereknek, ezért nagyon nehéz az országok tipizálása abból a szempontból, ahogyan kezelik ennek a családtípusnak a speciális problémáit. Néhány évtizeddel korábban Kamerman és Kahn (1988) megpróbált egy tipizációt felállítani, amelyben a témára vonatkozóan négy európai modellt különböztetett meg.

Az első modell az egyszülős családok problémáit kiterjedt szegénység politikán belül kezeli, amelyben egy meghatározott bevételi szint alatt mindenkit támogatásban részesítenek: a gyermeket nevelőt éppúgy, mint a gyermektelent, a fiatalt és az időset, az egyszülős családokat és a kétszülősöket egyaránt, akkor, ha anyagi helyzetük alapján rászorulónak nyilvánítják. Ide sorolják a szerzők például az angol modellt.

A második modellnek azt tekintik, amikor egy adott országban felismerik az egyszülős családok speciális nehézségeit, és egy olyan támogatási rendszert dolgoznak ki, amelyben kifejezetten az egyszülős családok a kedvezményezettek, mely igaz például Norvégiára, ahol erősen támogatják, hogy a kisgyermekü- 
ket egyedül nevelő szülők hosszabb ideig otthon maradjanak a gyermekkel, és ez alatt az időszak alatt anyagi támogatásban részesüljenek.

A harmadik modellbe azokat a típusokat sorolják, ahol kiemelt figyelmet fordítanak a kisgyermekes családok támogatására. Ezen belül kisebb-nagyobb további támogatást kaphatnak az egyszülős családok, de a hangsúly feltétlenül azon van, hogy a kisgyermekes anyák eldönthessék, hogy gyermekük három éves koráig otthon maradnak-e vagy sem, és amennyiben a válaszuk nem, akkor is megfelelő támogatásban részesülhessenek. Ebbe a csoportba sorolják a francia családpolitikát.

A negyedik modell azoknak az országoknak a családpolitikáját testesíti meg, amelyek a munka és a családi teendők összehangolásának támogatására teszik a hangsúlyt. Így például arra, hogy az anyák minél nagyobb arányban, és a gyermek megszületése után viszonylag hamar belépjenek/visszalépjenek a munka világába. Ennek középpontjában a munkaerőpiaci politikák dominanciája áll. Alapelv, hogy a családok fő megélhetési forrását a munkaerőpiaci jövedelemnek kell képezni, és minden állami támogatás csak kiegészítő jellegủ legyen, átmeneti időre szóljon vagy olyan társadalmi csoportok segitését célozza, akik valamiIyen speciális okból nem tudnak integrálódni a munkaerőpiacra. Ez a modell egy kiterjedt, területileg és társadalmi rétegek szerint is széles körben hozzáférhető gyermekellátórendszer működését is feltételezi, hiszen a szülők - különösen az egyedülálló szülők - csak akkor tudnak a munkaerőpiac aktív tagjai lenni, ha a gyermekek napközbeni ellátása rugalmasan biztosított. Ezt a modellt az akkori tipizációban a svéd politika testesítette meg.

Az utóbbi évtizedek európai politikáiban a legnagyobb hangsúlyt a munkaerőpiaci integrációt segítő támogatások kapták. E mögött alapvetően az a megfontolás áll, hogy a szegénységi kockázatot alapvetően az csökkenti, ha valaki dolgozik. Gyermekes családok esetében ez nem lehet független attól, hogyan alakul a gyermekek nappali ellátását biztositó intézmények hozzáférhetősége. Hol, hogyan, milyen anyagi terhek mellett tudják elhelyezni a szülők a gyermekeiket napközben? Különösen nagy jelentősége van ennek az egyszülős családok esetében, ahol a háztartáson kívül élő szülő az esetek többségében kevésbé vesz részt a gyermekek napközbeni ellátásában. Továbbá az sem egyértelmü, hogy a munkaerőpiaci részvétel hasonló módon csökkenti a szegénység kockázatát különböző társadalmi csoportokban. A munka világába integrálódottak is lehetnek szegények, az függ a munkaerőpiaci pozíciójuktól, és függ attól is, hogy a munkaerőpiaci bevételeket milyen módon használják fel a családban, és hogy a foglalkoztatott személynek hány inaktív családtagot kell eltartania. 


\section{EGYSZÜLŐS CSALÁDOKRA IRÁNYULÓ TÁRSADALOM- POLITIKÁK ÉRTELMEZÉSI KERETE}

Az alábbiakban bemutatjuk azt az értelmezési keretet, amelyen belül az egyszülős családpolitikákat taglaljuk. Ahogyan korábban is említettük, ezek vizsgálatánál több vonatkozásban is ki kell tágítanunk a nézőpontunkat. Nem csak azokat a területeket kell áttekintenünk, ahol közvetlen állami támogatás jelenhet meg, hanem mindazokat is, ahol az állam bármilyen formában csökkentheti az egyenlőtlenségeket, különösen a férfiak és a nők közöttieket. Ez azért jelentős, mert az egyszülős családok döntő többségében az anyák a háztartásfők, így egy olyan országban, ahol jelentős a nők és a férfiak közötti egyenlőtlenség, ott szükségszerűen hátrányos helyzetbe kerülnek az egyszülős családok is.

Elsőként arra mutatunk rá, hogy az apai szerepek hogyan alakulnak az egyszülős családok életében. A különélő szülőtől kapott támogatás intenzitása ugyan alapvetően az individuális jellemzőkön múlik, de jelentős a társadalmi meghatározottsága is. Utóbbi adja az alapját annak, hogy megvizsgáljuk, mit tesz az állam az apai szerepek megerősítésében, az apák jogainak és kötelezettségeinek erőteljesebb hangsúlyozásában.

A másik nagy terület a munkaerőpiac: miként alakulnak egy országban a férfiak és a nők közötti esélykülönbségek a munkaerőpiacon, mekkorák a kereseti differenciák. Hogyan integrálódnak a kisgyermekes anyák a munkaerőpiacra? Milyen keresetkiesést jelent számukra a gyermekvállalás a munkaerőpiaci életútban? Milyen védelmet kapnak a (kis)gyermeket nevelő szülők a munka világában? Mennyire rugalmas a munkavégzés ideje az egyes országokban?

A harmadik terület, ahol az államnak közvetlen és közvetett beavatkozási lehetősége is van, az a pénz- és természetbeni transzferek alakulása. Ezt gyakran közvetlenül kapcsolják a szegénypolitikához, noha ennek számos eleme kifejezetten nem a szegények támogatására irányul. Ilyen például az adórendszeren keresztüli redisztribució, de ide tartoznak azok a transzferek is, amelyek a gyermeket nevelő családokhoz alanyi jogon áramolnak (pl. a családi pótlék).

A gyermekes családoknak, de különösen az egyszülős családoknak nagy segítséget nyújthat, ha a gyermekek nappali ellátását biztosító állami intézmények területileg lefedik a gyermekes családok igényeit, ha ezeknek az intézményeknek a szolgáltatásai megfelelő színvonalúak, anyagilag hozzáférhetőek. Munkaerőpiaci szempontból különösen fontos, hogy az intézmények nyitvatartási ideje kellően rugalmas legyen. A gyermekek nappali ellátását biztosító intézmények rossz működése gyakorlatilag kizárhatja a kisgyermekét egyedül nevelő 
szülőket a munkaerőpiacról, ezért az ezzel kapcsolatos állami politikák kulcsszerepet töltenek be a családok életlehetőségeinek szempontjából.

Végül szeretnénk utalni annak a jelentőségére is, hogy az állam milyen támogatásokat ad, milyen pályázati lehetőségeket nyújt azoknak a civil szervezeteknek, amelyek az egyszülős családok érdekképviseletét látják el, és a legkülönfélébb programokkal, továbbképzéssel stb. próbálnak segíteni ezeknek a családoknak a helyzetén.

3. ábra: Az egyszülős családok életkörülményeit meghatározó tényezök és a társadalompolitikai beavatkozás lehetöségei

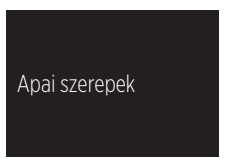

Az apai jogok és kötelezettségek erössége

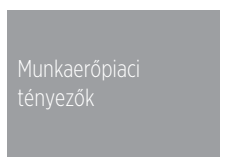

A nemek közötti egyenlőség alakulása a munkaeröpiacon

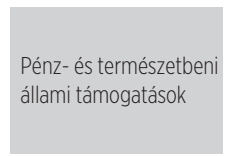

Pénzbeli támogatások a (kis)gyermeket nevelöknek

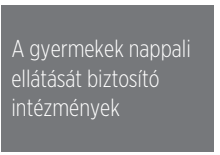

Kedvezmények, téritésmentesség az intézmények szolgáltatásainak igénybevételénél

A gyermeket nevelố apák pozitív diszkriminációja a munkaerőpiacon

Tartásdij fizetési problémák állami szintü kezelése
Férőhely hiány esetén a bekerüléskor pozitív diszkrimináció

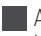

A gyermeket nevelők támogatása/védelme a munkaerőpiacon

A rugalmas munkavégzés elterjedtsége

A gyermekeiket egyedül nevelö szülők közvetlen támogatása a munkaerőpiacon

A gyermeküket egyedül nevelö szülők munkakeresésének támogatása
Pénzbeli és természetbeni támogatások az alacsony jövedelmủ családoknak

Adórendszeren keresztüli támogatások

Családi kedvezmények a szabadidôs intézmények látogatásakor

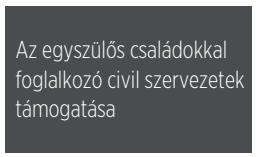

\section{támogatása}

Forrás: Saját szerkesztés.

\section{APAI SZEREPEK}

Kutatások bizonyítják, hogy azokban az országokban, ahol a párkapcsolatban élő szülők közötti egyenlőbb munkamegosztására nagyobb ösztönzők hatnak, ott a válás utáni apai szerep is erősebb maradhat (Isd. pl. Kalmijn, 2015). Ez mind anyagilag, mind pedig érzelmileg fontos támogatást jelenthet az egyszülős családoknak. A skandináv országokban hosszú hagyományai vannak annak, hogy 
az apák gyermeknevelésben betöltött szerepét jogszabályokkal is próbálják növelni (Bergman and Hobson, 2002; Dommermuth and Kitterød, 2009; Oláh et al., 2002). Ezt szolgálja, például az ún. apa kvóta, ami azt az időszakot jelenti, amit kizárólag az apák használhatnak fel kisgyermekeik gondozására. Svédországban az apa kvótát 1995-ben vezették be, majd 2002-ben és 2016-ban megnövelték az igénybe vehető időszakok hosszát. (Hasonló rendszer működik még például Norvégiában és Izlandon is.) Ráadásul a skandináv modell a munka és a gyermekgondozási feladatok egyenlőbb megosztását akkor is ösztönzi, amikor a szülők nem élnek együtt. Ha nem is ilyen kiterjedt értelmezésben, de apa kvóta Európa már országaiban is működik, például Németországban vagy Portugáliában.

Az apa kvóta bevezetése egyértelműen egy társadalompolitika eszköz. Ugyanakkor itt is utalni kell arra, hogy az apa kvóta hatékony müködésének, a kitüzött célok elérésének komoly korlátja lehet például, hogy ha egy országban nagy a nők és a férfiak keresete közötti különbség. Ha ugyanis az apák lényegesen többet keresnek, mint az anyák, akkor az apa kvótát akkor sem fogják igénybevenni a férfiak, ha az egyébként elveszik, hiszen a keresetkiesés jelentős. Fontos szerepe van továbbá az attitűdöknek is, amelyek több szinten kedvezőtlenül befolyásolhatják, hogy az apák éljenek az apa kvóta lehetőségével. A munkaadók, a kollégák, a családi és baráti közeg pozitív hozzáállása mind fontos szempont lehet. A munkaadók részéről ez munkaszervezési kérdés is, hiszen az apa ilyenkor néhány hétig kiesik a munkából. Érdekes eredményt hozott például egy finn kutatás, amely kimutatta, hogy Finnországban az attitűdök erősebben gátolták, hogy az apa otthon maradjon a gyerekkel, mint a család anyagi helyzete. Svédországban az apa kvóta igénybevételét egyértelműen a család anyagi helyzete befolyásolta, és az attitűdöknek nem volt szerepe, hiszen ott az apák erőteljes bekapcsolódása a gyermekvállalásba általánosan elfogadott (Salmi and Lammi-Taskula, 2014).

Magyarországon nincs apa kvóta, de van apai szabadság, amit az apa a gyermek születése utáni első két hónapban vehet igénybe, és melynek hossza öt munkanap (az uniós ajánlás fele). Erre az időtartamra a munkaadó távolléti díjat fizet. A Magyar Államkincstár adatai szerint ezt az apáknak csak nagyon kis része (2014-ben körülbelül negyede) veszi igénybe (Központi Statisztikai Hivatal, 2019b). Ez feltehetően azzal magyarázható, hogy a távolléti díjat a munkaadónak kell megelőlegeznie, így ők ellenérdekeltek az apai szabadság kiadásában. Ez nyilvánvalóan nem segíti az apák családon belüli munkavállalásának növekedését, és ahogyan említettük, válás esetén ez mind fontos előzményét jelenti a különélő szülő és a gyermek kapcsolatának. 


\section{A különélő szülőtől kapott támogatás, a tartásdíj fizetés problémái}

A háztartáson kívül élő szülő rendszeres anyagi támogatása meghatározó lehet az egyszülős családok jövedelmi helyzetében. Az Európai Unió életkörülményeket és jövedelmi helyzetet vizsgáló adatfelvételének (Statistics on Income and Living Conditions [SILC]) 2012-re vonatkozó adatai azt mutatták, hogy meglehetősen nagy a szórás a tekintetben, hogy a gyermeket egyedül nevelő családok mekkora aránya kap anyagi segítséget a különélő szülőtől (4. ábra). Ez nem jelenti azt, hogy a tartásdíj más csatornákon keresztül ne jutna el az egyszülős családokhoz, hiszen az állam több országban is komoly garanciát jelent arra, hogy az elmaradt tartásdíjat állami forrásokból előlegezze meg. Svédországban ez tényleges garanciát jelent, ezért ott, ha a különélő szülő nem fizet gyermektartást, akkor az állam átvállalja a kifizetést. Másutt viszont az egyszülős családoknak csak töredéke kapja meg a tartásdíjat. Ezek között is találunk olyan országokat, ahol a tartásdíj elmaradása esetén az állam jogszabály szerint megelőlegezi azt, de számos okból kifolyólag ezek a rendszerek hézagosan működhetnek.

A tartásdíjban részesülő egyszülős családok arányát az is befolyásolhatja, hogy az egyes országokban eltérő azoknak az aránya, ahol a gyermek születése óta egy szülő él, illetve ahol az egyik szülő halála miatt lett egyszülős a család. Írországban és az Egyesült Királyságban például nagyon magas azoknak az aránya, akik a gyermek születésétől fogva egyedül nevelik a gyermeküket, egy részüknél az apa nem elérhető, vagy maguk az anyák sem kívánják vele tartani a kapcsolatot. A dél-európai országokban pedig azoknak az egyszülős családoknak az aránya magas, ahol özvegyülés okozta a párkapcsolat végét. Ezekben az esetekben nyilvánvalóan eleve kizárt a háztartáson kívül élő szülő támogatása.

Ahogyan fentebb is említettük az egyes európai országok nagyon különbözőek abból a szempontból, hogy a tartásdíj elmaradása esetén milyen eszközöket alkalmaznak annak kikényszerítésére. ${ }^{2}$ Több országban megfigyelhető, hogy a tartásdijj kikényszerítését közvetlenül egy állami szerv végzi (pl. Magyarország, Svédország, Németország, Ausztria), míg másutt önkormányzati hatáskörbe tartozik a kérdés (pl. Csehország, Dánia, Finnország). Vannak olyan országok is, ahol a tartásdíjjal kapcsolatos ügyeket egy önálló szervezet intézi, ilyen például Hollandia, Dánia vagy az Egyesült Királyság. Az Egyesült Királyságban például a Child Support Agency (2014-től Child Maintenance Service), Dániában a Statsamt, Hollandiában pedig a National Agency Collecting Child Support szervezetek intézik a tartásdíjjal kapcso-

\footnotetext{
${ }^{2}$ Az alábbiakban ismertetett szabályozások a 2010-es évek elejéről származnak.
} 
latos ügyeket. Az egyszülős családok élethelyzetén javíthat, hogy magánbiztosító társaságok is fedezhetik az elmaradt tartásdíjakat, úgy mint Franciaországban.

\section{4. ábra: Gyermektartási dijjban részesülő családok aránya az egyszülős családok körében, 2012}

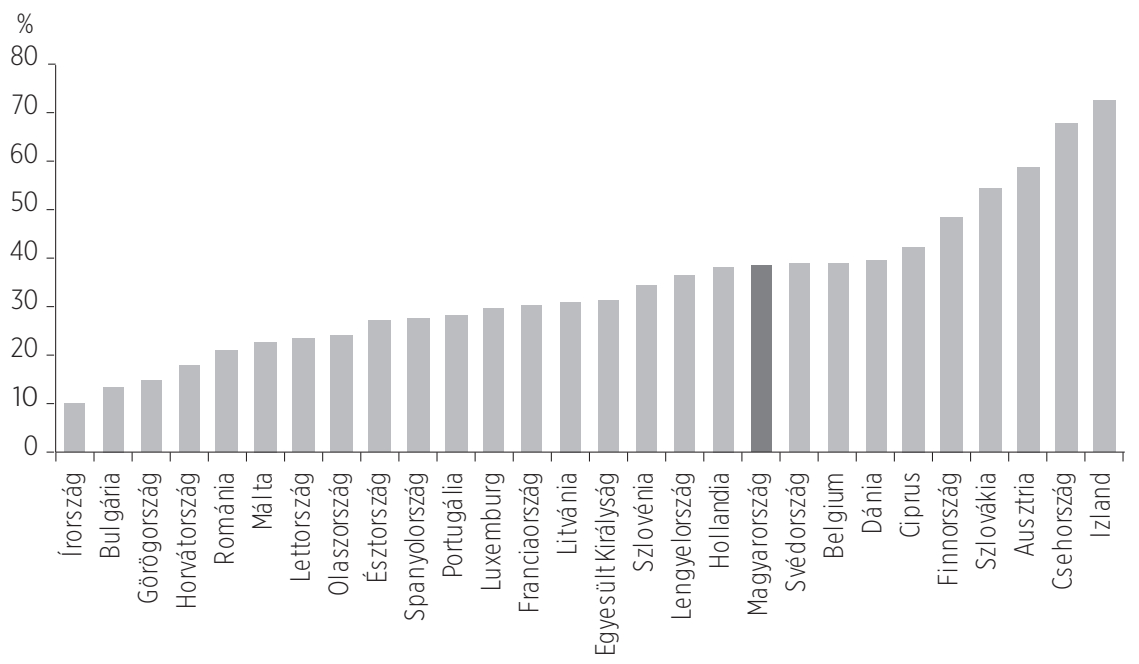

Forrás: EU-SILC 2012-re vonatkozó adatai. Saját számítás.

Megjegyzések: 1.) Az adatok azoknak a 18 éves vagy fiatalabb gyermekeknek az arányát mutatják, akik egyszülős családban élnek, és ahol az ott élő gyermekek közül legalább egy után gyermektartást fizet a különélő szülő. Mivel a tartásdijat az EU-SILC-ben háztartási szintủ adatként kérdezik, nem tudjuk, hány gyerek után kap tartásdíjat a család. 2.) Ezekben az adatokban azok a tartásdijak jelennek meg, amit a különélő szülő közvetlenül fizet a családnak. Ha a tartásdijat az állam előlegezi meg, akkor ezek nincsenek benne ebben az adatban.

Magyarország vonatkozásában - a fent említett SILC vizsgálat kivételével ez idáig nem ismerünk olyan adatközlést, ami a tartásdíjban részesülő családok számáról tájékoztatott volna. A lakossági adatfelvételekben számos torzítással kell számolnunk, hiszen a háztartáson kivül élő és a gyermekét egyedül nevelő szülő kapcsolata nagymértékben befolyásolhatja, hogy a gyermekek után fizetett tartásdíjat megjelenítik-e a kérdezettek a bevételi forrásaik között, illetve hogy ha igen, akkor reális képet adnak-e a tartásdíj nagyságáról.

Az Életünk Fordulópontjai adatfelvétel 2016-os hullámának erre vonatkozó adata azt mutatja, hogy azok közül a családok közül, ahol legalább egy olyan 18 éves vagy fiatalabb gyermek élt, aki korábbi párkapcsolatból származott, 57\%-ot tett ki azoknak az aránya, akiket a különélő szülő rendszeres anyagi támogatásban részesített. Az esetek túlnyomó többségében (70\%) ezekben a családokban egy ilyen gyermek élt. 22\%-ot tett ki, ahol két olyan kiskorú gyermeket is neveltek, aki korábbi kapcsolatból született, és $8 \%$ volt a három vagy több ilyen gyermekesek 
aránya. A gyermekek szemszögéből azt mondhatjuk, hogy az adatfelvétel szerint a kiskorú gyermekek 61\%-a kap a háztartáson kívül élő szülőtől rendszeres támogatást. ${ }^{3}$ 13\%-uknál a szülő meghalt vagy nem tudják, hogy hol tartózkodik. Ezekben az esetekben nyilvánvaló a rendszeres támogatás hiánya, de a fennmaradó 87\% esetében indokolt lehet az anyagi támogatás. Egyszóval a gyermekek mintegy negyedének életben van a különélő szülője, tudják, hogy hol él, de anyagi támogatást nem kapnak tőle (saját számítások, Életünk Fordulópontjai adatfelvétel 5. hulláma, 2016).

Abban az esetben, ha a háztartáson kívül élő szülő nem fizeti a tartásdíjat, és az átmenetileg behajthatatlanná vált, a gyámhivatal a tartásdíjat megelőlegezi. Erre akkor kerülhet sor, ha a gyermeket gondozó családban az egy főre jutó jövedelem nem éri el az öregségi nyugdíjminimum háromszorosát (ez az összeg 2018-ban 57000 Ft). A folyósítás legfeljebb három évig tarthat, amely időszak a feltételek fennállása esetén további három évvel meghosszabbítható. Ha a bíróság által megállapított tartásdíj összegének legalább felét a fizetésre kötelezett szülő eljuttatja a gondozó család felé, akkor a tartásdíj megelőlegezést nem lehet igénybe venni. A megelőlegezett tartásdíj összege gyermekenként nem haladhatja meg a nyugdíjminimum felét, amely jelenleg 14500 Ft.

Mindazok ellenére, hogy a lakossági adatok nagyon alacsony lefedettséget jeleznek a tartásdíj fizetés vonatkozásában, a megelőlegezett gyermektartási díjban részesülők száma is kevésnek mondható. 2017-ben csak valamivel több, mint 8400 gyermek részesült ebben a támogatási formában, és a kifizetett öszszeg is rendkívül alacsony volt (KSH, 2019b).

\section{AZ EGYSZÜLŐS CSALÁDOK MUNKAERÖPIACI HELYZETE ÉS A MUNKAERÖPIACI POLITIKÁK}

Ahogyan fentebb említettük, a nők és a férfiak munkaerőpiaci esélykülönbségei, a foglalkoztatási és kereseti különbségek jelentős mértékben befolyásolhatják a családok életkörülményeit. A különbségeket csökkentő szakpolitikák hatékony müködése különösen fontos azokban az esetekben, ahol a családban kisgyermekek nevelkednek, méginkább azokban, ahol a szülö - Európa számos országában döntő többségében az anya - egyedül neveli a gyermekét. Több kutatás mutatja ugyanis, hogy a nemek közötti különbségek a gyermek

\footnotetext{
${ }^{3}$ Ez az arány sokkal magasabb, mint amit a SILC adatokból számítottunk. Lehetséges, hogy ennek az az oka, hogy az Életünk Fordulópontjai adatfelvételben az összes olyan anyagi támogatásra rá lett kérdezve, ami a különélő szülőtől rendszeres támogatásként az egyszülős családhoz áramlik. Ez nem minden esetben tartásdíj. De számolnunk kell azzal is, hogy ezeknek az adatoknak a bevallása általában pontatlan.
} 
születése körüli időszakban kezdenek jelentősebben megnövekedni, és számos vonatkozásban fennmaradnak a gyermeknevelés teljes periódusa alatt (Grimshaw and Rubery, 2015; Joyce and Xu, 2019; Miller, 2018). Az, hogy a gyermekvállalás milyen mértékben töri meg az anyák munkaerőpiaci karrierjét, hogy milyen hosszú távú hatásai vannak a gyermekvállalásnak, és hogy milyen hátrányokban csapódik le mindaz, amikor egy anya egyedül neveli tovább a gyermekét, az nem csak a munkaerőpiaci politikáktól függ. A családpolitikai intézkedések, a segélyezés, a gyermekek napközbeni ellátását biztosító intézmények működése, a gyermekellátási időszak hossza és szintje mind meghatározó elemek ebből a szempontból.

Mint a legtöbb európai országban, így Magyarországon is a nők foglalkoztatási mutatói rendre elmaradnak a férfiakétól. A különbség egyik magyarázata, hogy a nők nyugdíjbavonulási életkora általában alacsonyabb, mint a férfiaké. A korcsoportos foglalkoztatási mutatók viszont azt is jelzik, hogy a gyermekvállalás is jelentősen befolyásolja ezt a különbséget, ugyanis a férfiak és a nők foglalkoztatottsága közötti különbség éppen a gyermekesek körében a legnagyobb. Az anyák mutatóit viszont erősen differenciálja, hogy együttélő

5. ábra: Foglalkoztatási ráta az anyák és az apák különböző csoportjaiban Magyarországon, 2005-2017

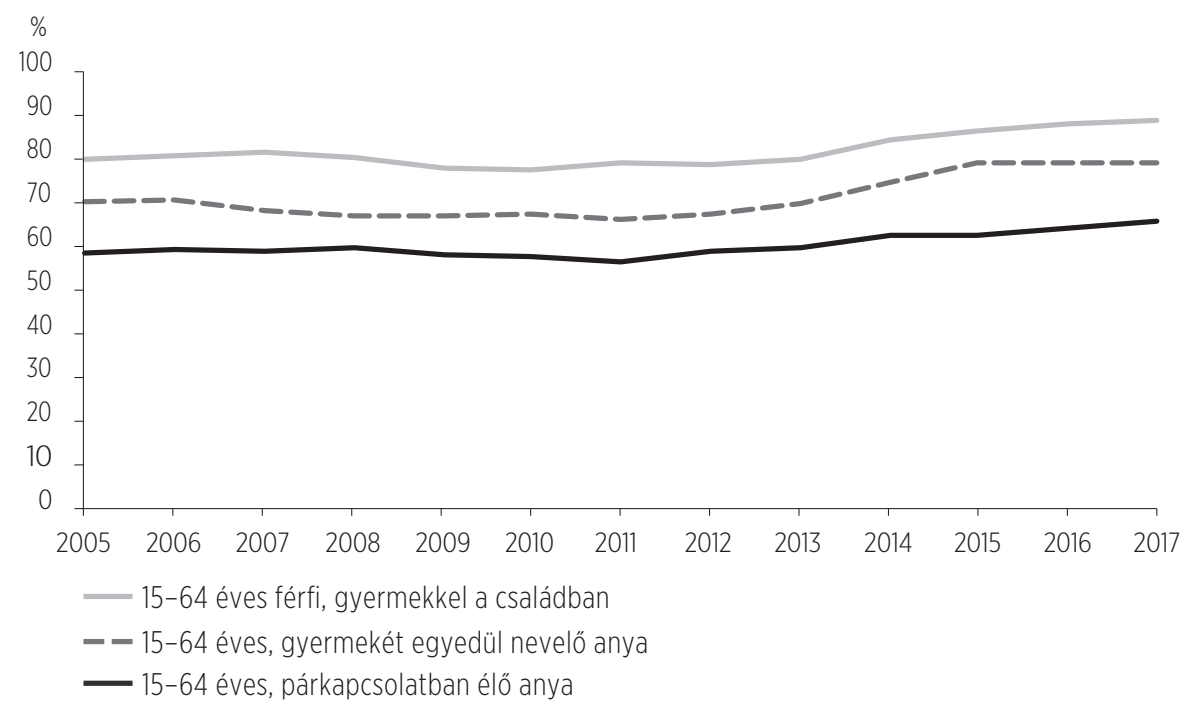

Forrás: Eurostat (2019a).

Megjegyzések: 1.) Apának és anyának azokat tekintettük, akik gyermekkel élnek egy családban szülő státuszban, függetlenül attól, hogy vér szerinti gyermekükkel élnek-e vagy sem. 2.) Az apák esetében nem bontottuk meg a párkapcsolatban élőket és a gyermeküket egyedül nevelőket, mert ez utóbbiak nagyon kevesen voltak. 
6. ábra: Foglalkoztatási ráta az anyák és az apák különböző csoportjaiban iskolai végzettség szerint Magyarországon, 2005-2017

ISCED 0-2

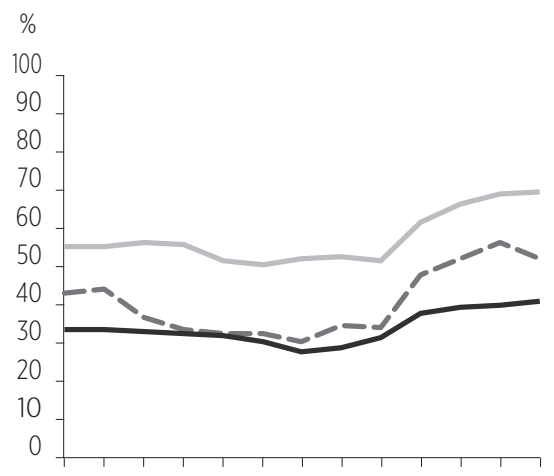

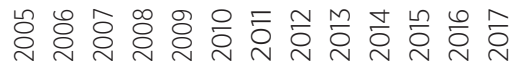

ISCED 3-4

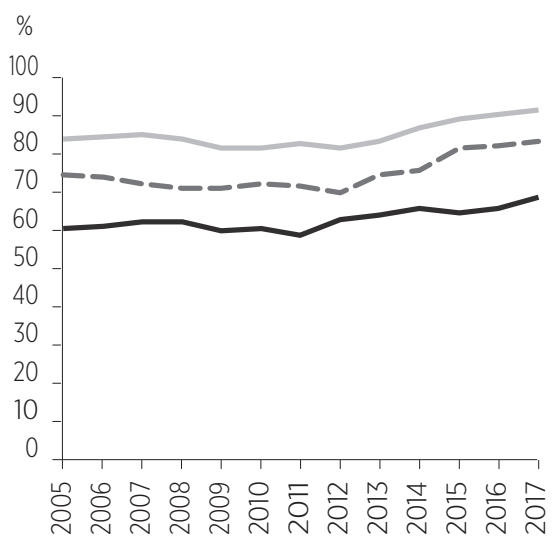

ISCED 5-8

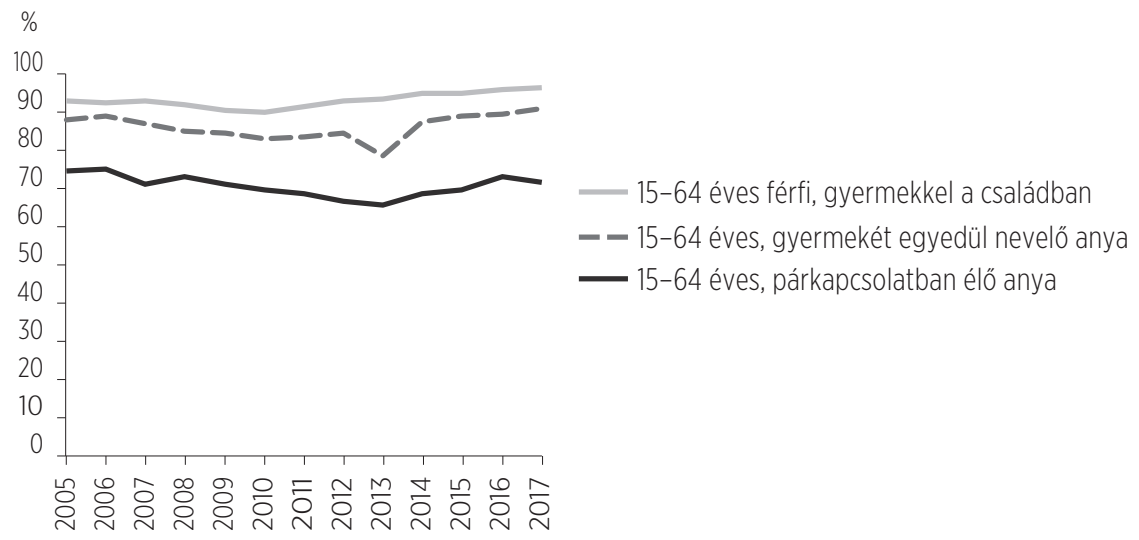

Forrás: Eurostat (2019a).

Megjegyzés: Az iskolai végzettség nemzetközi osztályozása mentén kialakitott kategóriák a következők: ISCED 0-2: érettségit nem adó végzettségek; ISCED 3-4: érettségit adó végzettségek; ISCED 5-8: felsőfokú diplomát adó végzettségek.

párkapcsolatban vagy egyedül nevelik-e gyermekeiket. Magyarországon az egyszülős anyák foglalkoztatottsága magasabb (az utóbbi években 80\% körüli), mint a párkapcsolatban élőké (5. ábra). Ez minden iskolai végzettségi szinten így van (6. ábra). Ennek az lehet az oka, hogy az egyszülős anyák ösztönző tényezői erőteljesebbek, hiszen ha nem dolgoznak, akkor a család kereső nélkül maradhat. 
A legutóbbi években erőteljesen növekedett az iskolai hierachia alján elhelyezkedő, gyermeküket egyedül nevelő anyák foglalkoztatottsága. 2010 körül ennek a csoportnak a foglalkoztatottsági rátája alig haladta meg a 30\%-ot, az utóbbi években viszont rendre 50\% felett van. Ez feltehetően összefüggésben van a 2010-es években bevezetett közmunka programmal, amely az alacsony iskolai végzettségü társadalmi csoportok munkaerőpiaci integrációját célozta meg. Az emelkedő trend ellenére azonban még mindig rendkívül alacsony ennek a rétegnek a foglalkoztatási mutatója. Ezeknek a családoknak valószínűleg támaszt jelenthet, hogy az átlagosnál nagyobb arányban élnek három generációs családban, így szüleik is segítik őket a megélhetésben (Harcsa és Monostori, 2017).

A gyermeküket egyedül nevelő magyar anyák foglalkoztatottsága európai összehasonlításban kifejezetten magasnak tekinthető. Sajátossága még, hogy mindössze két olyan ország van hazánkon kívül, ahol a gyermeküket egyedül nevelő nők foglalkoztatottsága ilyen jelentősen meghaladja a párkapcsolatban élő anyákét. Meglepő módon azok az országok vannak többségben, ahol a gyermeküket egyedül nevelő nők mutatói elmaradnak a párkapcsolatban élő anyáktól (7. ábra). Sokféle magyarázat állhat e mögött, és hozzá kell tenni, hogy a gyermeküket egyedül nevelő anyák foglalkoztatottsági mutatójának időbeli trendje nagyon különböző. Az általunk vizsgált 2017-es adatok csak egyetlen időpontot ragadnak meg, és nem mutatják, hogy melyik ország merre tart a folyamatban. Az ír anyák munkaerőpiaci integrációját például alapvetően határozza meg az a tény, hogy Írországban a gyermekek nappali gondozása alapvetően piaci alapon működik, és a térítési díjak rendkívül magasak. Több gyermek esetén már mindenképpen mérlegelés tárgyát képezi, hogy megéri-e a gyermekét egyedül nevelő szülőnek viszszatérnie a munkaerőpiacra. Egy OECD-vizsgálat kimutatta, hogy Írországban két iskolás kor előtti gyermek teljes idős nappali ellátása az egyszülős családok átlag jövedelmének 40\%-át teszi ki, míg az OECD-országok átlaga 14\% (Maldonado and Nieuwenhuis, 2015; Millar and Crosse, 2016). Hollandiában fontos szerepe lehet annak, hogy a munkanélküli, gyermekét/gyermekeit egyedül nevelő szülő a gyermek öt éves koráig mentességet kap a munkakeresés alól. A munkanélküliség periódusa alatt a minimálbér 70\%-át kapja, melynek az a feltétele, hogy ezen időszak alatt olyan képzéseken vegyen részt, amelyek a későbbi munkaerőpiaci integrációját szolgálják. Ez az intézkedés komoly ellenösztönzőként működhet. Az időbeli trendek fontosságára mutat rá az Egyesült Királyság példája, mely szerint láthatjuk, hogy egy hosszú évtizedek óta tartó komplex munkaerőpiaci eszköztár próbálja a gyermeküket egyedül nevelő anyák foglalkoztatottsági szintjét megemelni. 1996 és 2013 között a foglalkoztatottsági rátájuk 43-ról emelkedett 60\%-ra. Ezen időszak alatt a párkapcsolatban élő anyák mutatója csak 5 százalékponttal növeke- 
dett (Klett-Davies, 2016). Az angol egyszülős anyák foglalkoztatottsági mutatója tehát elmarad a párkapcsolatban élő anyákétól, de a trend egyértelműen arra utal, hogy a gyermeküket egyedül nevelők mutatói felzárkózóban vannak.

7. ábra: Foglalkoztatottsági ráták a gyermekes nök különböző csoportjaiban, 2017

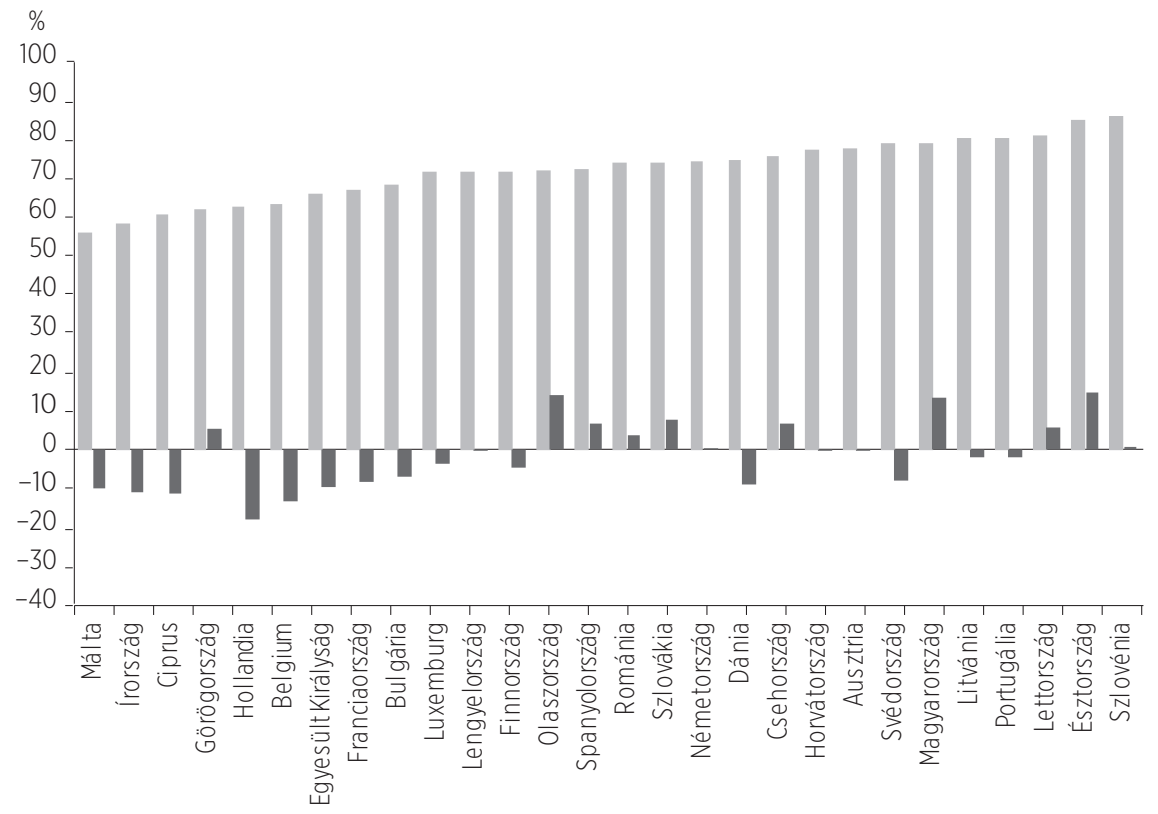

Egyszülős anya

Az egyszülős anyák és a párkapcsolatban élő anyák foglalkoztatottsága közötti különbség

Forrás: Eurostat (2019a).

A munka és a családi teendők összehangolását jelentősen segithetik a rugalmas munkaformák. Magyarországon ezt szolgálja például a 2012. évi I. törvény, amely kimondja, hogy a három éven aluli gyermeket nevelő szülő, illetve három vagy több gyermek nevelése esetében a legkisebb gyermek öt éves koráig a munkavállaló kérésére a munkaadó köteles részmunkaidőben foglalkoztatni a munkavállalót. Ugyanakkor a munkaadónak csak a négy órás munkaidőre vonatkozó kérést kötelessége elfogadni, a hat órás munkaidő elfogadását mérlegelheti. A részmunkaidős foglalkoztatási forma ott tud igazán hatékonyan működni, ahol egy részmunkaidős kereset is megélhetést tud biztosítani, és ez az egyszülős családoknál szinte kizárt. Sokkal nagyobb jelentősége van azoknak a szakpolitikai eszközöknek, amelyek a munkavégzés idejének rugalmasságát tudják biztosítani. Ezeknek a támogatására 
irányult Magyarországon a családbarát munkahely program, melynek értelmében támogatást kaphatnak azok a munkáltatók, akik valamilyen eszközzel megpróbálják segíteni a családi teendők és a munkahelyi feladatok összehangolását. Egy 2013-2016 közötti, 10 főnél több dolgozót foglalkoztató cégekre kiterjedt magyar kutatás azt mutatta, hogy a vizsgált, több mint 10 ezer cégnek a 67\%-a vette figyelembe a munkaidő beosztásnál, a szabadságok kiadásánál az oktatási intézmények nyitvatartását. 57\% biztosította a részmunkaidős munkavállalás lehetőségét, 42\% a rugalmas munkavégzést, 35\% nyújtott iskolakezdési támogatást, 28\% szervezett családi programokat, 14\% biztosított munkaidő kedvezményt a gyermeket nevelőknek és $11 \%$ biztosította a távmunka vagy az otthoni munka lehetőségét. A vizsgált vállalatok 31\%-a semmilyen, 35\%-a egy, 26\%-a kétféle kedvezményt nyújtott dolgozóiknak (Tóth et al., 2018). Ráadásul ezek a lehetőségek számos esetben csak egyegy speciális élethelyzetben alkalmazhatók, úgy mint az otthoni munka lehetősége vagy a rugalmas munkakezdési/munka befejezése időpont csak olyan napokon vehető igénybe, amikor a gyermek beteg.

Európai összehasonlításban azt mondhatjuk, hogy az időben és térben rugalmas munkavégzés Magyarországon nem igazán jellemző. A munkaidő szempontjából a legrugalmatlanabb munkaerőpiac a dél- és kelet-európai országokban található. Noha van néhány olyan kelet-európai ország, ahol kicsit kedvezőbb a helyzet, mint például Észtország, Lengyelország vagy Szlovénia, azonban Litvániában, Szlovákiában vagy Romániában sokkal rosszabb a helyzet. Magyarországon a női munkavállalók 76\%-a mondta azt, hogy semmilyen befoIyása nincs a munkaidő beosztását tekintve, azt teljes mértékben a munkaadó határozza meg. Ez az arány Dániában 35\%, Svédországban és Hollandiában 37\%, Norvégiában 41\%. A kontinentális Európában, például Ausztriában, Németországban és Franciaországban is 56-58\% közötti értéket láthatunk (8. ábra).

A kisgyermekes anyák támogatásának egyik fontos eleme lehet, hogy a munkavállaló is érdekelté válljon az alkalmazásukban. Magyarországon ezt kívánja előremozdítani a Munkahelyvédelmi Akcióterv is, amely a korábbi Startkártyához hasonlóan kedvezményeket ad a munkaadónak, amennyiben olyan kisgyermekes munkavállalót alkalmaz, aki még gyermeknevelési ellátást kap. Ezen kívül még több, általában a Munka Törvénykönyvében rögzített intézkedés védheti a kisgyermekes szülőket, ezen belül is a gyermeküket egyedül nevelőket. Azért fogalmazunk így, mert nem tudjuk, hogy a mindennapi gyakorlatban hogyan érvényesül a törvény betűje. A Munka Törvénykönyve ${ }^{4}$ ugyanis elöírja,

\footnotetext{
${ }^{4}$ A Munka Törvénykönyve azokat tekinti gyermekét egyedül nevelő szülőnek, aki a házastartársától külön él és/vagy nincsen élettársa.
} 
hogy a gyermekét egyedül nevelő munkavállaló a gyermek három éves koráig nem kötelezhető egyenlőtlen munkaidő-beosztásra. Ez azt jelenti, hogy a heti pihenőnapok nem oszthatók be egyenlőtlenül, éjszakai műszakra nem osztható be, és esetükben rendkivüli munkaidő vagy készenlét sem rendelhető el. Rendkívüli munkaidő vagy készenlét a gyermek három és négy éves kora között is csak nagyon speciális esetekben ( $p l$. baleset, elemi csapás stb.) lehetséges. Az egészségbiztosítási ellátásokról szóló törvény is megkülönbözteti a gyermeküket egyedül nevelő szülőket, hiszen ők több napig maradhatnak otthon táppénzen a beteg gyermekükkel. A gyermek 12 éves koráig mindkét szülőnek járó táppénz napot megkapja a gyermekét egyedül nevelő szülő, így a gyermek 1 és 6 éves kora között évi 84 napot, 6 és 12 év között évi 28 napot.

\section{8. ábra: Az európai női munkavállalók helyzete a munkaidő rugalmasságát tekintve, 2015}

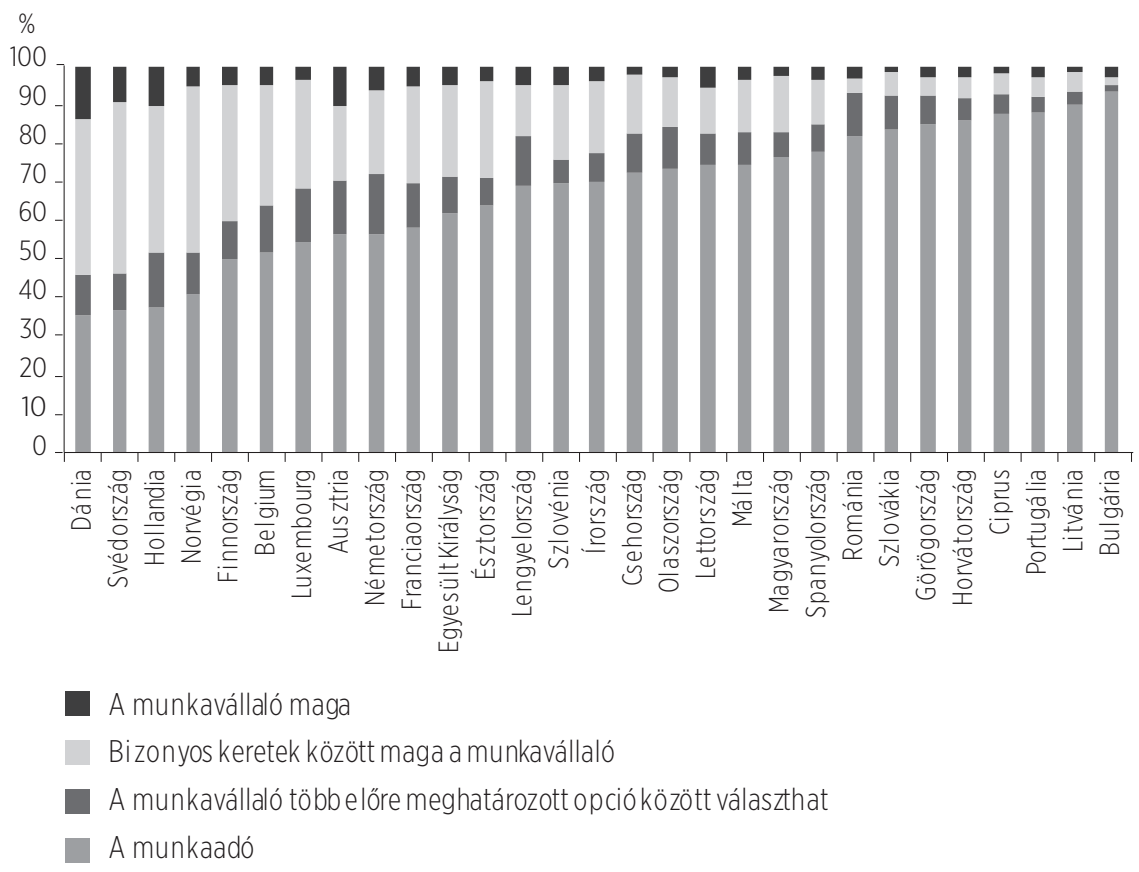

Forrás: European Working Conditions Survey, 2015.

Megjegyzés: A kérdés arra vonatkozott, hogy ki határozza meg a munkaidő beosztását.

A gyermeküket egyedül nevelő nők számára rendkívül fontos lehet, hogy ha munkanélkülivé válnak, akkor megfelelő aktivitással tudjanak munkát keresni, és a munkába állás körülményeit meg tudják teremteni. Magyarországon nincsenek olyan jogszabályok, amelyek a kisgyermeküket egyedül nevelő szülőket segite- 
nék ebben a helyzetben. Az Egyesült Királyságban például a munkaügyi hivatal által kiajánlott állásinterjúra nem a szokásos 48 órán belül, hanem 7 napon belül kell alkalmas időpontot találni, amennyiben a gyermek felügyeletét 48 órán belül nem tudja megoldani. Az új munka megtalálása után általános szabályként 7 napon belül munkába kell állni, azonban a kisgyermekét egyedül nevelő szülők esetében ez csak 28 nap. Így nagyobb eséllyel tudja megoldani a jövőbeli gyermekfelügyeletet. A munkakeresőknek általában a teljes idős munkára is készen kell állnia, de a gyermeküket egyedül nevelők ennél kevesebbre, minimum 16 órára kötelezhetőek. Ha a gyermek 13 év alatti iskolás, és a gyermekfelügyeletet nem tudják megoldani, akkor kivételes esetben még ennél is rövidebb időre kötelezhetőek.

A foglalkoztatottság mellett a keresetek szintje is hozzájárul a különböző családtípusokban élők életszínvonalának alakulásához. Általános európai jelenség, hogy az anyák bére nem csak az apáktól, hanem a gyermektelen nők bérétől is elmarad. Ennek nagyon jelentős részét magyarázza a háztartáson belüli specializáció, nevezetesen, hogy a gyermek születése után az anyák nagyobb részt vállalnak a gyermekek ellátásában, a háztartási munkákban, míg az apák a pénzkeresésre fókuszálnak (Angelov et al., 2016; Davies and Pierre, 2005; Grimshaw and Rubery, 2015; Kleven et al., 2018; Miller, 2018). Érdekes tény, hogy a gyermekvállalás több országban is már azelőtt befolyásolja a munkaerőpiaci döntéseket, mielőtt a gyermek megszületne. Ez feltehetően azzal (is) magyarázható, hogy a gyermekvállalás komoly negatív hatással van a nők munkaerőpiaci karrierjére, és eleve korlátozzák a munkaerőpiaci potenciáljukat, például azzal, hogy olyan foglalkozást választanak, ami támogatja a gyermekvállalást, viszont nem jár magas bérrel (Adda et al., 2017). A kelet-európai országokban az anyák és a leendő anyák bérhátránya jelentősebb, mint több nyugat-európai országban, és ez az iskolai végzettség hatásának kontrolálása után is megmarad. Ebből az következik, hogy ha a munkaerőpiaci és a családi feladatok ellátása egy országban nehézségbe ütközik, akkor az feltétlen bérhátránnyal jár, elsősorban a gyermeket vállaló vagy tervező anyák számára (Lovász et al., 2018). Ez, ahogyan említettük, akkor válik igazán éles kérdéssé, amikor a nő partner nélkül marad, és egyedüli keresőként kell magát és a gyermekeit eltartania.

A bérek és a foglalkoztatottság alakulása nem független egymástól, bár a két tényező nem mindig ugyanúgy kapcsolódik össze. Érdekes példa lehet néhány dél-európai ország, ahol azért nem mutattak ki az anyák és a gyermektelen nők között bérkülönbséget, mert az anyáknak egy jelentős része a gyermek vállalása után végleg kilép a munkaerőpiacról. Csak a legmotiváltabbak maradnak a 
munka világában, így a bérkülönbségek ezen szelekciós mechanizmus miatt eltűnnek. A kis bérkülönbség ára tehát a gyermekes nők alacsony foglalkoztatottsága (Lovász et al., 2018).

A kelet-európai országban magasabbak a gyermekes anyák foglalkoztatási mutatói, mint a déli országokban, viszont jelentősebb a bérlemaradásuk. Kutatások arra utalnak, hogy ezekben az országokban nagyon hatékony lenne a munka és a családi teendők összeegyeztethetőségét szolgáló politikák erőteljesebb megjelenése.

\section{AZ EGYSZÜLŐS CSALÁDOK ÉS A SZEGÉNYSÉG}

Az Európai Unió EU-SILC (Statistics on Income and Living Conditions) kutatása egyértelmủen rávilágít arra, hogy az egyszülős családok jövedelmi szegénységben való érintettsége jelentősen meghaladja az adott országra jellemző átlagos értéket, de lényegesen magasabb azoknál a mutatóknál is, amelyek a gyermeküket/gyermekeiket párkapcsolatban nevelő szülők családjaira jellemzőek. ${ }^{5}$ Néhány országban a szegénységi ráta és annak az országos átlagtól való eltérése is drámai mértéket ölt. A magyarországi helyzet mind az egyszülős családokban élők szegénységi rátája, mind az országos átlagtól való eltérés szempontjából kedvezőtlen képet mutat. 2016-ban a vizsgált családok 38\%-a élt az ekvivalens jövedelem 60\%-ánál kisebb összegből, míg az országos átlag ugyanebben az időpontban 14\%, a két szülős gyermekes családokban 16\% volt (9. ábra).

Az időbeli trendeket vizsgálva azt mondhatjuk, hogy miközben a három vagy több gyermekes családok szegénységi rátáját az utóbbi másfél évtizedben sikerült csökkenteni, addig ez az egyszülös családok esetében nem történt meg.

Az egyszülős családok magas szegénységi mutatói alapvetően arra vezethetők vissza, hogy ezekben a családokban rendkivül kedvezőtlen a jövedelemszerzők és a fogyasztók egymáshoz viszonyított aránya. Az állami és a háztartástól külön élő szülők átadott jövedelme pedig nem kompenzálja ezt a hátrányt. Emellett a gyermeküket egyedül nevelő szülők iskolai végzettség szerinti struktúrája a legtöbb országban kedvezőtlenebb, mint a párkapcsolatban élőké, ami nyilvánvalóan meghatározza a munkaerőpiaci helyzetüket, keresetüket is.

\footnotetext{
${ }^{5}$ Az egyszülős családok magas, a gyermekes családok körén belül is kiemelkedő szegénységi rátája nem új jelenség. Erre a korábbi évtizedek európai kutatásai is rámutattak. Maldonado és Nieuwenhuis (2015) például 18 OECD-ország 1978 és 2008 közötti vonatkozó adatait elemezte.
} 
9. ábra: A jövedelmi szegénységben élők aránya a szülők különböző csoportjaiban, 2016

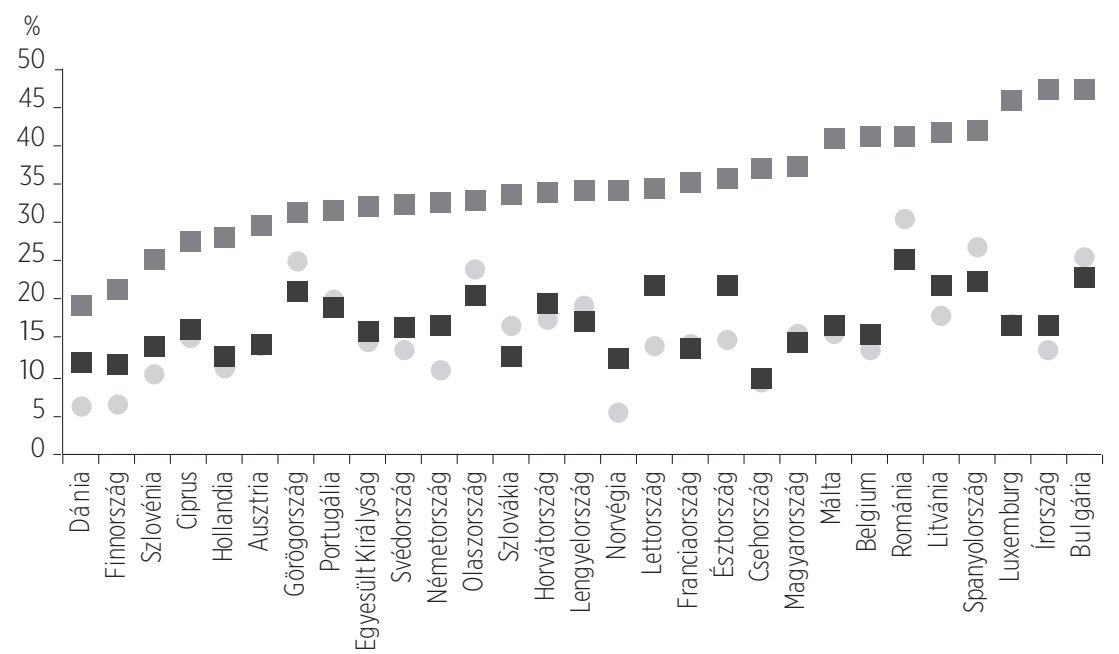

Gyermekét egyedül nevelő szülő

Párkapcsolatban élő szülő

- Összesen

Forrás: Eurostat (2018a).

Megjegyzés: Jövedelmi szegénynek azokat tekintjük, akiknek a háztartásában az egy fogyasztási egységre jutó transzferek utáni - jövedelem nem éri el a medián jövedelem 60\%-át.

Ugyanakkor ezek a - szegénységet meghatározó - tényezők országonként, társadalmi rétegenként és egyénenként is különböző súllyal vannak jelen. Láttuk például, hogy Magyarországon a gyermeküket egyedül nevelő nők foglalkoztatottsági mutatói az európai átlagnál kedvezőbbek, és magasabbak a magyar, párkapcsolatban élő nőkhez képest. Ellenben szegénységi mutatóik nem alacsonyabbak az európai átlagnál, és a párkapcsolatban élők mutatóinál, melyből következik, hogy Magyarországon az egyszülős családok annak ellenére vannak az átlagnál sokkal nagyobb szegénységi kockázatnak kitéve, hogy a gyermeket egyedül nevelők közül európai szinten az átlagosnál többen dolgoznak. Ezt a jelenséget mutatja az az ábra, amely a foglalkoztatottak körén belül méri a szegények arányát (10. ábra). 2017-ben Magyarországon a párkapcsolatban élő, gyermeket nevelő, foglalkoztatottak 6\%-a élt a szegénységi küszöb alatt, míg a gyermeket egyedül nevelőknek 24\%-a. Emellett a gyermekeiket egyedül nevelők relatív helyzete is romlott: 2005-ben 13\%-ot, 2010-ben 12\%-ot, 2015-ben már 21\%-ot tett ki a szegények aránya a foglalkoztatottak körén belül. 
10. ábra: A jövedelmi szegénységben élők aránya a gyermeküket egyedül nevelő foglalkoztatottak körében, 2017

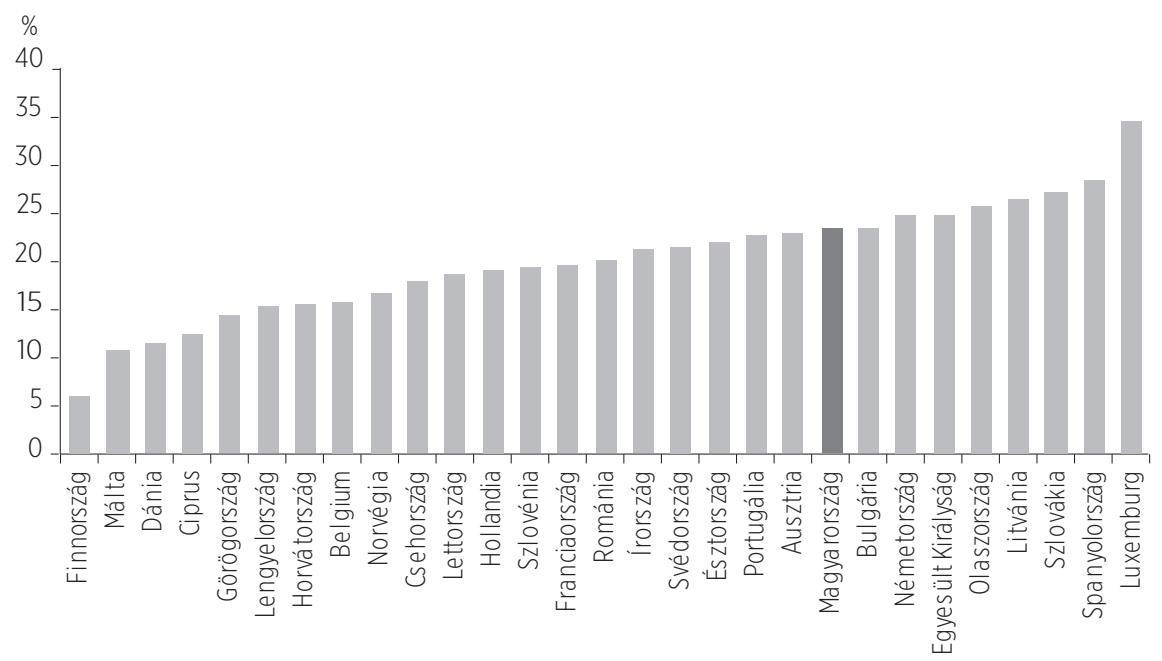

Forrás: Eurostat (2019b).

Az egyszülős családok felé áramló transzferek egy része alanyi jogú rendszereken, míg mások inkább a szegénypolitika keretein belül jutnak el a családokhoz. A magyar rendszerben családi pótléknak nevezett ellátás általában Európa más országaiban is alanyi jogon jár a gyermekes családoknak. Abban viszont vannak eltérések, hogy az ellátás összege jövedelemfüggő-e. Több országban is változik az ellátás összege a szülők anyagi helyzetének függvényében, illetve több helyen érvényesítik azt az elvet, hogy a magasabb paritású gyermekek után magasabb az ellátás összege. Néhány országban - Magyarországon, Belgiumban, Észtországban, Portugáliában, Szlovéniában - az egyszülős családok családi pótléka magasabb összegü, másutt az egyszülősök támogatási kiegészítése csak egy bizonyos jövedelemhatár alatt történik (pl. Ciprus, Olaszország). Bőkezű ellátásnak tűnik az a megoldás, amikor az egyszülős családok annyi ellátásra jogosultak, mint ha egy gyermekkel több élne a családban (pl. Dánia, Norvégia). Magyarországon a differenciálás igen csekély, hiszen a gyermeküket egyedül nevelő családokban a családi pótlék összege alig 1000 forinttal haladja meg a párkapcsolatos családok támogatását. 2019-ben az egy gyermeket nevelő egyedülálló szülők 13700 Ft-ot kapnak, két gyermek esetén 29600 Ft-ot, három és több gyermek esetén gyermekenként 17000 Ft-ot. Ráadásul ennek a juttatásnak a reálértéke az utóbbi évtizedben jelentősen csökkent, hiszen az összege 2008 óta nem emelkedett. 
Magyarországon a gyermeküket egyedül nevelő szülők is megkaphatják a családi adókedvezményt, amely munkajövedelem és minden más adóköteles bevétel (pl. járadék) után is érvényesíthető. Arra vonatkozóan nincsenek adataink, hogy a gyermeküket egyedül nevelők ezt milyen mértékben tudják igénybe venni, de mivel az egyszülős családokban a gyermekszám átlag alatti, ez az esetek jelentős többségében havi 10 000-20 000 Ft-os adókedvezményt jelent számukra.

Abban az esetben ha a gyermektől távol élő szülő meghalt, akkor a gyermek a legtöbb országban árvasági ellátást kaphat. Magyarországon árvaellátásra az a gyermek jogosult, akinek a szülője a haláláig az öregségi nyugdíjhoz szükséges szolgálati időt megszerezte, ez például a 30-35 év közötti szülők esetében 8 év, 35-45 év közöttieknél 10 év, 45-55 év között 15 év. Az árvaellátás alapja az az összeg, amely a szülőt az elhalálozása időpontjában megillette volna, ezért a gyermek az így meghatározott összeg 30\%-át kapja meg. Az árvaellátás minimális összege 24500 Ft, ami 2007 óta nem változott. Ezt a támogatást a gyermek 16 éves koráig kapja, illetve ha nappali tagozatos tanuló, akkor legfeljebb 25 éves koráig. 2016-ban az árvasági ellátást havi átlagban 67 ezren kapták. Az ellátás havi, átlagos összege valamivel több, mint 40 ezer forint volt (Központi Statisztikai Hivatal, 2016).

Az egyes országok abban is jelentősen különböznek egymástól, hogy az állami transzferek milyen mértékben tudják segíteni a legelesettebb családokat. Ennek mérésére használhatjuk azt a mutatót, amely az egyes csoportokra jellemző szegénységi rátát az állami transzferek előtt és után is bemutatja. Az állami transzferek előtti szegénységi ráta azt fejezi ki, hogy mekkora lenne a szegények aránya az adott csoportban, ha az országban nem lenne társadalmi szintű újraelosztás.

E vonatkozásban azt láthatjuk, hogy Magyarországon az állami transzferek szegénység csökkentő hatása viszonylag jelentős. 2016-ban mindössze három olyan európai országot (Egyesült Királyság, Írország, Finnország) találunk, ahol a transzferek jelentősen nagyobb mértékben csökkentették a szegénységi rátát, mint nálunk. Hollandia, Ausztria és Ciprus a magyarhoz nagyon hasonló értékeket mutat, míg az összes többi országban a transzferek szegénység csökkentő hatása jelentősen alacsonyabb volt (11. ábra).

Arra vonatkozóan nincsenek adataink, hogy melyik országban mely transzferjövedelem szegénységcsökkentő hatása kiemelkedő. Azt viszont meg tudjuk vizsgálni, hogy az állami redisztribúció hatása hogyan érvényesül azokban a családokban, ahol a gyermekeket két szülő neveli. Milyen különbségeket fedezhetünk fel a kétszülős és az egyszülős családok felé áramló állami transzferek mértékében? Melyek azok a társadalmak, ahol a gyermekes családok felé erő- 
teljes a transzferáramlás, függetlenül attól, hogy a gyermekeket egy vagy két szülő neveli? És melyek azok, ahol az egyik vagy a másik irányába erőteljesebb újraosztási mechanizmusokat fedezhetünk fel?

11. ábra: A jövedelmi szegénységben élő egyszülős családok aránya az állami transzferek előtt és után, 2016

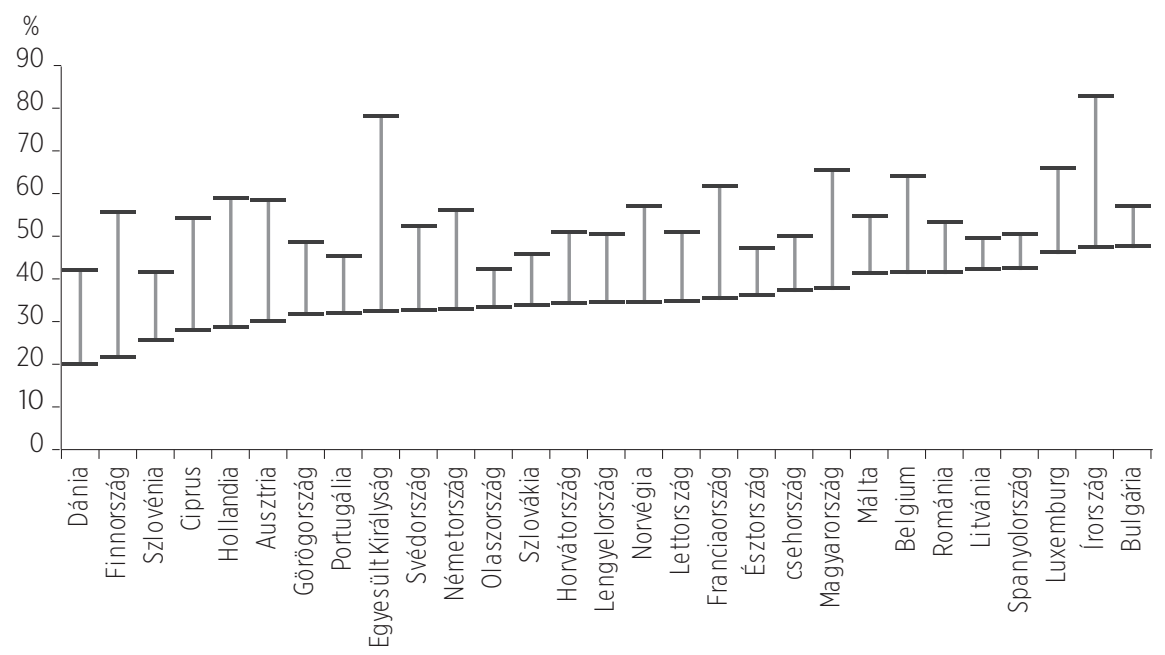

Forrás: Eurostat (2018b).

Megjegyzés: Az oszlopok alsó pontja a transzferek előtti, az oszlopok felső pontja pedig a transzferek utáni szegénységi rátát mutatja.

Az országok többségére - így Magyarországra is - jellemző, hogy az állami redisztribúció az egyszülős családok körében erőteljesebben csökkenti a szegénység kockázatát, mint a kétszülős családoknál (12. ábra). Az adatokat csak akkor tudjuk értelmezni, ha látjuk, hogy ez mennyiben magyarázható azzal, hogy az egyszülős családok erőforrásai, strukturális helyzete sokkal kedvezőtlenebb képet mutat, mint a kétszülősöké, vagy arra is látunk-e példákat, hogy az egyszülős családok felé nagyvonalúbb ellátások áramolnak, mint ahogy azt tényleges helyzetük indokolná. Általánosságban az országok többségénél inkább az előbbiről van szó, azaz a transzferek szegénységcsökkentő hatása azért erőteljes, mert az egyszülős családok redisztribúció előtti strukturális helyzete rendkívül kedvezőtlen.

Néhány országban (Egyesült Királyság, Írország, Finnország, Hollandia, Dánia) az egyszülős családok szegénységi rátáját a redisztribució lényegesen nagyobb mértékben csökkenti, mint a kétszülős családokét. Ez erőteljesen öszszefügg azzal, hogy az egyszülős és a párkapcsolatos családok transzferjövedel- 
mek előtti szegénységi mutatói ezen országok egy részében nagy különbséget mutatnak. Az Egyesült Királyságban vagy Írországban például az állami újraelosztás nélkül gyermeküket egyedül nevelő tíz szülő közül nyolc a szegénységi küszöb alá kerülne, miközben a párkapcsolatban élők transzferjövedelmek előtti szegénységi mutatója az Európai Unió átlagához hasonló. Tehát ezekben az országokban olyan magas az egyszülős családok szegénységi kockázata, hogy a transzferjövedelmek igen erőteljes átcsoportosítást hajtanak végre.

12. ábra: Az állami transzferek szegénységcsökkentő hatása az egy- és a kétszülös családokban, 2016

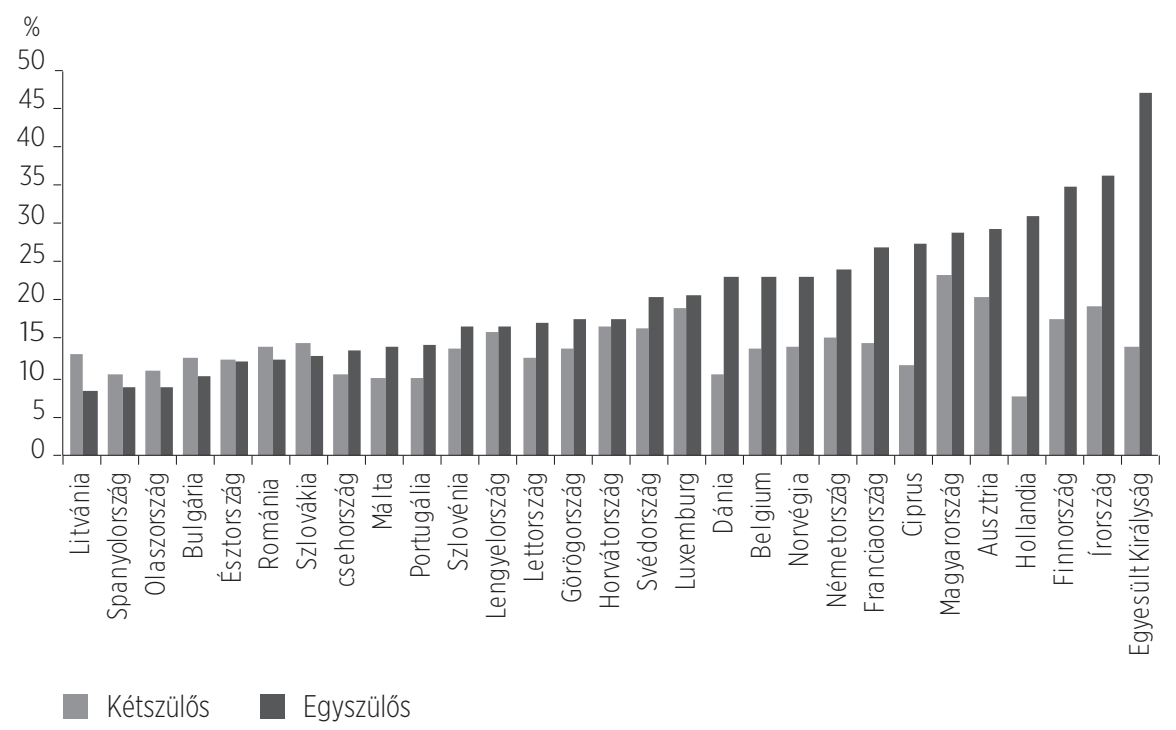

Forrás: Eurostat (2018b).

Megjegyzés: Az ábra azt mutatja meg, hogy az állami transzferek hány százalékkal csökkentik az adott csoport szegénységi rátáját.

Ha az egyszülős családok problémáit komplexen nézzük, nem hagyhatjuk figyelmen kívül azt a tényt sem, hogy ezek társadalmi integrációját, részvételét, a kulturális intézmények támogatását segítő programok is feltűnően hiányoznak a magyar gyakorlatból. Ebben a vonatkozásban az egyszülős családok hátrányai nem csak a párkapcsolaton alapuló, legalább három gyermeket nevelő családokhoz képest dokumentálhatók, hanem összességében azokhoz képest is, akik párban nevelik a gyermekeiket. Az egyszülős családok a kulturális és szabadidős intézmények látogatásakor számos esetben nem vehetik igénybe a családi kedvezményeket. 


\section{AZ EGYSZÜLÖS CSALÁDOK ÉS A NAPPALI GYERMEK- GONDOZÁS INTÉZMÉNYEI}

Az egyszülős családok szegénységi kockázatának csökkentésében alapvető szerepe van annak, hogy a gyermeküket egyedül nevelő szülők hogyan tudnak integrálódni a munkaerőpiacra, illetve milyen pozíciókat tudnak betölteni ott. Ez úgy tud jól működni, ha a gyermekek nappali ellátása biztosított. Ezen intézmények működése a párkapcsolatban élő szülők számára is kulcskérdés, de az egyszülős családokban különösen nagy jelentősége van annak, hogy biztosított-e az intézményekhez hozzáférés, mekkora térítési díjakat kell fizetni, és mennyire rugalmasak az intézmények például a tekintetben, hogy mikortól-meddig lehet azokat igénybe venni.

A skandináv országokban például a nappali gyermekgondozás intézményei széles hozzáférést biztosítanak a gyermekeknek, így azokat a gyermekeket, akiket a szüleik nem otthon gondoznak, felveszik a bölcsődékbe. Emellett például a finn szabályozás szerint az alacsony jövedelmü családoknak nem kell térítési díjat fizetniük (Forssén, 2015). Ebből következően a skandináv országokban a három év alatti gyermekek sokkal nagyobb hányadát gondozzák intézményi keretek között, mint más európai országokban (13. ábra). A három év feletti gyermekek intézményi ellátottságát vizsgálva - ez lényegében a hazai óvodás kornak felel meg - az országok közötti különbségek sokkal kisebbek.

13. ábra: A három év alatti gyermekek intézményes nappali ellátásában résztvevő gyermekek aránya, 2007 és 2016

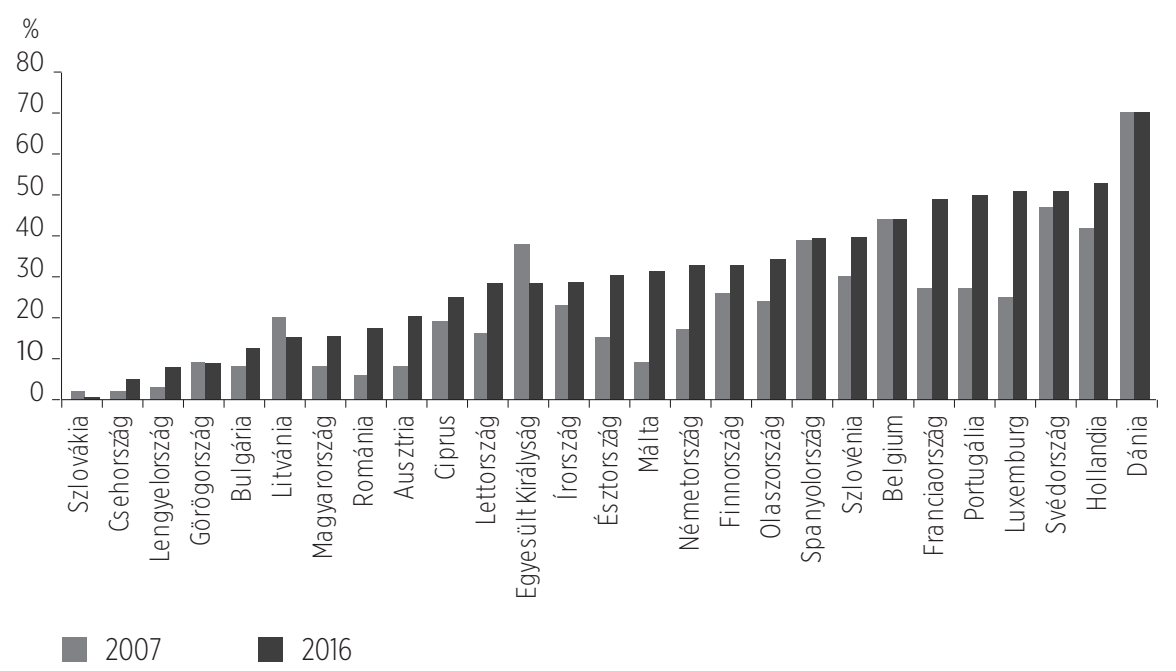

Forrás: Eurostat (2018c). 
Nyilvánvalónak tűnik, hogy az egyszülős családok erőteljesebben szorulnak rá a gyermekek nappali ellátását biztosító intézmények működésére, mint a párkapcsolatban élők. Kutatások adatai alapján mégis azt látjuk, hogy azok az európai országok vannak többségben, ahol a párkapcsolatban élő szülők gyermekei részesültek nagyobb arányban intézményi ellátásban. Egy 2010-re vonatkozó kutatás mindössze Svédországot, Hollandiát, Ausztriát, Lengyelországot és Németországot emelte ki, ahol az egyszülős családok gyermekeinek intézményes nappali ellátása számottevően kiterjedtebb volt, mint a párkapcsolatban élő szülőké. Magyarország egyébként szintén ebbe a körbe tartozott, de az egyszülős családok gyermekeinek érintettsége csak nagyon kis mértékben haladta meg a párkapcsolatban élő szülők gyermekeinek intézményes ellátottságát (Van Lancker, 2018). E vonatkozásban fontos, hogy ha a gyermekét egyedül nevelő szülő dolgozik vagy munkát keres, akkor gyermeke a bölcsődei felvételnél előnyt élvez.

A bölcsődék és az óvodák működésének megítélése szempontjából az is meghatározó, hogyan alakul a nyitvatartásuk és mennyire tudják rugalmasan kezelni a különböző élethelyzeteket. Ebben a tekintetben is számottevő a különbség az európai gyakorlatban. Magyarországon a bölcsődék jogszabályban előirt minimális nyitvatartási ideje 10 óra, bár ez európai viszonylatban hosszúnak számít, ráadásul hazánkban sok bölcsőde 12 órán át is nyitva tart.

\section{AZ EGYSZÜLŐS CSALÁDOKKAL FOGLALKOZÓ CIVIL SZER- VEZETEK}

Az egyszülős családok problémáinak jelentős részével igazán hatékonyan a civil szervezetek tudnak foglalkozni. Magyarországon viszonylag kevés azoknak a civil szervezeteknek a száma, akik kifejezetten az egyszülős családokkal foglalkoznak. Bár a családszervezetek döntő többsége feléjük is nyitott, de náluk nyilván kevésbé hangsúlyosan jelennek meg a problémáik. A legnagyobb egyszülősökkel foglalkozó civil szervezet az Egyedülálló Szülők Klubja Alapítvány, melynek célja az egyszülős családok társadalmi esélyegyenlőségének elősegítése. Az alapítvány 2005 óta működik, azonban igazán láthatóvá 2018 májusában vált, amikor egy 500 millió forintos állami támogatással egy budapesti központot nyitottak. Tevékenységük sokrétü, többek között kiterjed jogi, munkaügyi, pszichológiai és mediációs tanácsadásra is. A központ mobil irodaként is szolgál, és helyet biztosít az egyszülős családok gyermekeinek korrepetálására, továbbá számtalan tudományos és szélesebb közönségnek szóló előadásnak, konferenciának ad hely- 
színt. Ebben a központban játszóház is müködik, ahol a gyermekek eltölthetik az idejüket, amíg a szülők a különböző programokon vesznek részt. Honlapjukon számos jogszabály ismertetése megtalálható, amelyek a különböző élethelyzetekben levő egyedül nevelők szülőknek nyújthat hasznos információt. Az utóbbi évben vidéken is több helyen nyitottak irodákat, annak érdekében, hogy az ott élő egyszülős családoknak is segíthessenek.

Az említett központon kivül nem tudunk olyan civil szervezetről, amely hasonló nagyságrendű állami támogatással tud foglalkozni az egyszülős családok problémáival. Az egyszülős családok problémái gyakran a nőket vagy anyákat tömörítő civil szervezetekbe, közösségekbe csatornázódnak be, ahol néhány ember lelkesedése, hatalmas munkabefektetése müködteti a szervezetet. Ezek időről időre elnyernek kisebb önkormányzati támogatásokat, pályázatokat, de rendszeres bevételük lényegében nincs.

\section{ÖSSZEGZÉS}

Tanulmányunkban az egyszülős családok életkörülményeinek azon területeire igyekeztünk rámutatni, amelyekben a társadalompolitikának beavatkozási lehetőségei vannak. Ezeken a területeken megpróbáltunk rávilágítani a fő kihívásokra, majd számba vettük azokat az eszközöket vagy éppen hiányosságokat, amelyekkel erre a magyar társadalompolitikai intézkedések reagálnak.

Az európai országokat áttekintve elmondhatjuk, hogy az egyszülős családok sehol sem kiemelt célcsoportjai a társadalompolitikai intézkedéseknek. Ugyanakkor azokban az országokban, ahol az egyenlőtlenségek kisebbek, ahol a nők és a férfiak esélyegyenlősége jobban megvalósul, ott az egyszülős családok helyzete is kedvezőbben alakul. Ez a családok jövedelmi helyzetében, a szegénységi kockázatban is megmutatkozik, de a tartásdíj fizetési hajlandóság is nagyobb, ami az egyszülős családok számára a legfontosabb elsődleges segítség. Az egyes európai országok nagyon különböznek abban is, hogy az elmaradt tartásdíj pótlásában milyen hatékonysággal müködnek. Bár a legtöbb európai ország foglalkozik ezzel a kérdéssel, a tartásdíj fizetés megelőlegezése csak kevés országban müködik igazán jól. Az általunk ismert (sajnos régebbi) adatok szerint Svédországban vagy Dániában például majdnem 100\%-os lefedettséggel tudják állami szinten „,pótolni” az elmaradt tartásdíjat. Magyarországon ez nem működik elég hatékonyan, ráadásul a tartásdíj megelőlegezése csak meghatározott ideig és meghatározott jövedelmi szint alatt igényelhető. Emellett a fizetett összeg csak töredéke annak, amiben a különélő szülőtől kellene részesülnie a családnak. 
Mivel a gyermekeit egyedül nevelő szülők többsége nő, a férfiak és a nők munkaerőpiaci esélykülönbségei is meghatározóak. Magyarországon a női foglalkoztatottság általában magas, de a kisgyermekes anyák munkaerőpiaci részvétele alacsony, mely visszavezethető a rendkívül bőkezü és hosszú ideig tartó anyasági ellátásokra. Noha komoly szakmai viták folynak arról, hogy a gyermek fejlődése szempontjából mi lenne az ideális időtartam, amíg az anyjukkal otthon maradhatnak, munkaerőpiaci szempontból ez a rendszer a nők számára kedvezőtlen, ugyanis túl hosszú időre esnek ki a munkaerőpiacról, ami a későbbi karrierjük, bérük szempontjából is hátrányos lehet. Bizonyos vonatkozásokban eddig a GYED extra sem érte el a kivánt hatását, hiszen a kisgyermekes anyák foglalkoztatottsága nem növekedett szignifikánsan. Azzal, hogy az apák is igénybe vehetik a GYED-et, nem feltétlenül az apák gyermekkel otthon töltött ideje növekedett. Számos esetben az apa továbbra is dolgozik, és igénybe veszi a GYED extrát, míg az anya ellátatlanul marad otthon a gyermekkel (Isd. erről: Vékony-Kovács, 2018). Mindezeknek rendkívül negatív hatása van, ha a kapcsolat felbomlik, és az anya egyedül neveli tovább a gyermekét, hiszen egy töredezett munkaerőpiaci pálya áll mögötte. Az ellátás nélküli időszakok pedig még a nyugdíjas éveire is hatással lesznek. A másik fontos munkaerőpiaci jelenség, hogy Magyarországon a nemek közötti keresetkülönbség nagyon felerősödik a gyermeket nevelők körében. A gyermek születése után - bizonyos esetekben már közvetlenül előtte is - a férfiak növelik, a nők csökkentik a munkaerőpiaci potenciáljukat. Ez összefüggésben van azzal, hogy nálunk erősen tartja magát a hagyományos férfi-női munkamegosztás, miszerint a gyermeknevelést, a háztartási munkákat a női, míg a munkaerőpiaci feladatokat a férfi dominancia jellemzi. Ez akkor válik égető kérdéssé, amikor a párkapcsolat felbomlása után az anya munkaerőpiaci aktivitása a korábbinál erősebb szerepet kap a család életkörülményeinek alakulásában.

Munkaerőpiaci szempontból nem csak a foglalkoztatottság és a keresetek szintje meghatározó, hanem a munkavégzés formájának rugalmassága is. Az egyszülős családok esetében ez nem annyira a részmunkaidős álláslehetőségek kibővitésének szükségességét jelenti, hanem sokkal inkább az otthon dolgozás, a napi munkaidő rugalmas beosztásának megteremtését. Ebben a vonatkozásban az európai országokhoz képest Magyarországon igen kedvezőtlen a helyzet.

Az egyszülős családok szegénysége jelentősen meghaladja az országos átlagot, melynek több oka is van. Az egyik, hogy a gyermekeit egyedül nevelő szülők társadalmi jellemzői kedvezőtlenebbek, mint a párkapcsolatban élőké. A másik, hogy a családszerkezetből adódóan az egyszülős családokban általában kedvezőtlenebb az eltartó/eltartott arány. A harmadik ok viszont egyértelmű- 
en az, hogy a társadalompolitika nem tudja az egyszülős családok kedvezőtlen helyzetét megfelelő mértékben kompenzálni. Ez a helyzet annak ellenére fennáll, hogy a pénzbeli transzferek szegénységcsökkentő hatása európai viszonylatban jelentős. Ennek oka, hogy az egyszülős családok hátrányos helyzete mögött más, erőteljesen ható mechanizmusok müködnek, mint például a kisgyermekes nők bérhátránya. Ezzel magyarázható az is, hogy miközben Magyarországon átlag feletti az egyszülős nők foglalkoztatottsága, a szegénységi mutatóik az országos átlaghoz képest és a gyermekes családok körén belül is magasak. Ezekből az következik, hogy az egyszülős családok helyzetének érdemi javítása egy komplex intézkedéscsomagot igényelne, amelyben munkaerőpiaci, családpolitikai és segélyezési elemek is jelen vannak. Ez a konklúzió egybevág annak a kötetnek a végkövetkeztetésével, amely európai országokban vizsgálta az egyszülős családok helyzetét, és arra jutott, hogy az egyéni erőforrások növelése, a munkaerőpiaci részvétel emelése és a hatékony társadalompolitikai segítségnyújtás egyidejüsége talán egyik családtípusnál sem olyan fontos, mint az egyszülős családoknál (Maldonado and Nieuwenhuis, 2018). 


\section{IRODALOM}

Adda, J., Dustmann, C., Stevens, K. (2017). The career costs of children. Journal of Political Economy, 125(2), 293-337.

Angelov, N., Johansson, P. and Lindahl, E. (2016). Parenthood and the gender gap in pay. Journal of Labor Economics, 34(3), 545-579.

Bergman, H. and Hobson, B. (2002). Compulsory fatherhood: The coding of fatherhood in the Swedish welfare state. In B. Hobson (Ed.), Making men into fathers: Men, masculinities and the social politics of fatherhood (pp. 92-124). Cambridge: Cambridge University Press.

Bitler, M. P., Gelbach, J. B., Hoynes, H. W. and Zavodny, M. (2004). The impact of welfare reform on marriage and divorce. Demography, 41(2), 213-236.

Blaskó Zs. (2016). Transznacionális családok, hátrahagyott gyerekek Dél- és KeletEurópában. Socio.hu Társadalomtudományi Szemle, 6(1), 71-88. doi: 10.18030/socio. hu.2016.1.71

Davies, R. and Pierre, G. (2005). The family gap in pay in Europe: A cross-country study. Labour Economics, 12(4), 469-486.

Dommermuth, L. and Kitterød, R. H. (2009). Fathers' employment in a father-friendly welfare state: Does fatherhood affect men's working hours? Community, Work \& Family, 12(4), 417-436.

Eurostat (2015). Private households by type, tenure status and NUTS 2 region [cens_11htts_ r2]. Elérhető: https://ec.europa.eu/eurostat/data/database

Eurostat (2018a). At-risk-of-poverty rate by poverty threshold and household type - EUSILC survey [ilc_li03]. Elérhető: https://ec.europa.eu/eurostat/data/database

Eurostat (2018b). At-risk-of-poverty rate before/after social transfers (pensions included in social transfers) by household type - EU-SILC survey [ilc_li09b]. Elérhető: https://ec.europa.eu/eurostat/data/database

Eurostat (2018c). Children in formal childcare or education by age group and duration - \% over the population of each age group - EU-SILC survey [ilc_caindformal]. Elérhetö: https://ec.europa.eu/eurostat/data/database

Eurostat (2019a). Employment rate by sex, age groups, educational attainment level and household composition (\%) [lfst_hheredty]. Elérhető: https://ec.europa.eu/eurostat/ data/database

Eurostat (2019b). In-work at-risk-of-poverty rate by household type - EU-SILC survey [ilc_iw02]. Elérhető: https://ec.europa.eu/eurostat/data/database

Forssén, K. (2015). Improving the employment opportunities of lone parents in Finland. Nem publikált kézirat.

Fransson, E., Låftman, S. B., Östberg, V. and Bergström, M. (2018). Wellbeing among children with single parents in Sweden: Focusing on shared residence. In L. C. Maldonado and R. Nieuwenhuis (Eds.), The triple bind of single-parent families: Resurces, employment and policies to improve well-being (pp. 145-170). Bristol: Policy Press. 
Grimshaw, D. and Rubery, J. (2015). The motherhood pay gap: A review of the issues, theory and international evidence (Conditions of Work and Employment Series 57). Geneva: International Labour Office.

Grogger, J. and Bronars, S. G. (2001). The effect of welfare payments on the marriage and fertility behavior of unwed mothers: Results from a twins experiment. Journal of Political Economy, 109(3), 529-545.

Harcsa I. és Monostori J. (2017). A háztartás- és családszerkezeti változások hosszútávú trendjei Magyarországon európai kontextusban: Teóriák, tévképzetek, tények. Demográfia, 60(4), 299-332.

Harkness, S. and Salgado, M. F. (2018). Single motherhood and child development in the UK. In L. C. Maldonado and R. Nieuwenhuis (Eds.), The triple bind of single-parent families: Resurces, employment and policies to improve well-being (pp. 101-124). Bristol: Policy Press.

Jagannathan, R. and Camasso, M. J. (2003). Family cap and nonmarital fertility: The racial conditioning of policy effects. Journal of Marriage and Family, 65(1), 52-71.

Joyce, R. and Xu, X. (2019, April 3). The gender pay gap: Women work for lower-paying firms than men. Elérhető: https://www.ifs.org.uk/publications/14032

Kalmijn, M. (2015). Father-child relations after divorce in four European countries: Patterns and determinants. Comparative Population Studies, 40(3), 251-276.

Kamerman, S. B. and Kahn, A. J. (1988). What Europe does for single-parent families. Public Interest, 23(3), 70-86.

Klett-Davies, M. (2016). Under pressure? Single parents in the UK. Gütersloh: Bertelsmann Stiftung.

Kleven, H., Landais, C. and Søgaard, J. E. (2018). Children and gender inequality: Evidence from Denmark (NBER Working Paper 24219). Cambridge: National Bureau of Economic Research.

Központi Statisztikai Hivatal (2016). Szociális ellátórendszer 2016. Budapest: Központi Statisztikai Hivatal.

Központi Statisztikai Hivatal (2019a). Jövedelem-eloszlás, szegénység 2003-2018 [adatbázis]. A társadalmi haladás mutatószámrendszere. Elérhető: https://www.ksh.hu/ thm/2/indi2_6_1.html

Központi Statisztikai Hivatal (2019b): A családtámogatási és gyermekgondozási ellátások [adatbázis]. Stadat. Elérhető: http://www.ksh.hu/docs/hun/xstadat/xstadat_eves/i_ fsp006.html

Lovász A., Cukrowska-Torzewska E. és Szabó-Morvai Á. (2018). Karrier gyermekvállalás előtt és után. In Fazekas K. és Szabó-Morvai Á. (szerk.), Munkaerőpiaci tükör 2017 (161-163 o.). Budapest: MTA Közgazdaság- és Regionális Tudományi Kutatóközpont.

Maldonado, L. C. and Nieuwenhuis, R. (2015). Family policies and single parent poverty in 18 OECD countries, 1978-2008. Community, Work \& Family, 18(4), 395-415.

Maldonado, L. C. and Nieuwenhuis, R. (Eds.) (2018). The triple bind of single-parent families: Resurces, employment and policies to improve well-being. Bristol: Policy Press. 
Millar, M. and Crosse, R. (2016). Lone parents and activation, what works and why: A review of the international evidence in the Irish context. Galway: The UNESCO Child and Family Research Centre.

Miller, C. C. (2018. February 5). Children hurt women's earnings, but not men's (even in Scandinavia). The New York Times. Elérhető: https://www.nytimes. com

Oláh, L. S., Bernhardt, E. M. and Goldscheider, F. K. (2002). Coresidential paternal roles in industrialized countries: Sweden, Hungary, and the United States. In B. Hobson (Ed.), Making men into fathers: Men, masculinities and the social politics of fatherhood (pp. 25-57). Cambridge: Cambridge University Press.

Salmi, M. and Lammi-Taskula, J. (2015). Policy goals and obstacles for fathers' parental leave in Finland. In G. B. Eydal and T. Rostgaard (Eds.), Fatherhood in the Nordic welfare states: Comparing care policies and practice (pp. 303-324). Bristol: Policy Press.

Tóth I. J., Hajdú M. és Makó Á. (2018). Rugalmas foglalkoztatási formák és egyéb családbarát intézkedések a magyar vállalatok körében. In Fazekas K. és Szabó-Morvai Á. (szerk.), Munkaerőpiaci tükör 2017 (185-189. o.). Budapest: MTA Közgazdaság- és Regionális Tudományi Kutatóközpont.

Treanor, M. C. (2018). Income poverty, material deprivation and lone parenthood. In L. C. Maldonado and R. Nieuwenhuis (Eds.), The triple bind of single-parent families: Resurces, employment and policies to improve well-being (pp. 81-100). Bristol: Policy Press.

Van Lancker, W. (2018). Does the use of reconciliation policies enable single mothers to work? A comparative examination of European countries. In L. C. Maldonado and R. Nieuwenhuis (Eds.), The triple bind of single-parent families: Resurces, employment and policies to improve well-being (pp. 239-262). Bristol: Policy Press.

Vékony-Kovács I. (2018). A családtámogatási rendszer a kisgyermekes anyák szemszögéből. (Szakdolgozat, Károli Gáspár Református Egyetem Bölcsészettudományi Kar, Szociológia Tanszék). 


\section{SINGLE PARENT FAMILY POLICIES IN HUNGARY AND EUROPE}

\section{ABSTRACT}

The poverty rate of lone parent families is higher than the average and the coupled families with children in every European countries. What can the states do? How can they handle this problem? How are the state supports efficient? The study deals with these questions, points out that the lone parents families are not strongly supported group of different areas of social policy. The ideological reasons are very strong since the states try to avoid the surface that they support the divorce and the separation of coupled. On the other hand the fears of misuse are also very significant. In Hungary recently the difference of poverty rate of coupled parents families and lone parents families is higher than before. The reason is that in the last few years the state strongly supported the coupled parent families, especially the families with three or more children. They can receive family allowance, substantinal tax relief and housing support. The study overviews the distinction of labour market position of men and women, the shaping of fatherhood, the child family support system and also the state redistribution that can contribute to the life circumstances of lone parents families. It reveals some good practises in European countries that give subsantinal helps to these families. 